\title{
IGF2BP1 enhances HCV IRES-mediated translation initiation via the $3^{\prime}$ UTR
}

\author{
SUSAN WEINLICH, ${ }^{1}$ STEFAN HÜTTELMAIER, ${ }^{2}$ ANGELIKA SCHIERHORN, ${ }^{1}$ SVEN-ERIK BEHRENS, ${ }^{1}$ \\ ANTJE OSTARECK-LEDERER, ${ }^{1,3}$ and DIRK H. OSTARECK ${ }^{1,3}$ \\ ${ }^{1}$ Institute of Biochemistry and Biotechnology, Martin-Luther-University Halle-Wittenberg, 06120 Halle (Saale), Germany \\ ${ }^{2}$ NBL3-NWG6 ZAMED, Department of Medicine, Martin-Luther-University Halle-Wittenberg, 06120 Halle (Saale), Germany \\ ${ }^{3} \mathrm{Clinic}$ of Intensive Care Medicine, Experimental Research Group Intensive Care Medicine, University Hospital Aachen, RWTH Aachen, \\ 52074 Aachen, Germany
}

\begin{abstract}
The positive-strand RNA genome of the Hepatitis C virus (HCV) contains an internal ribosome entry site (IRES) in the 5 ' untranslated region (5'UTR) and structured sequence elements within the $3^{\prime}$ UTR, but no poly(A) tail. Employing a limited set of initiation factors, the HCV IRES coordinates the 5 ' cap-independent assembly of the 435 pre-initiation complex at an internal initiation codon located in the IRES sequence. We have established a Huh7 cell-derived in vitro translation system that shows a 3'UTR-dependent enhancement of 435 pre-initiation complex formation at the HCV IRES. Through the use of tobramycin (Tob)aptamer affinity chromatography, we identified the Insulin-like growth factor-II mRNA-binding protein 1 (IGF2BP1) as a factor that interacts with both, the HCV 5'UTR and 3' UTR. We report that IGF2BP1 specifically enhances translation at the HCV IRES, but it does not affect 5'cap-dependent translation. RNA interference against IGF2BP1 in HCV replicon RNA-containing Huh7 cells reduces HCV IRES-mediated translation, whereas replication remains unaffected. Interestingly, we found that endogenous IGF2BP1 specifically co-immunoprecipitates with HCV replicon RNA, the ribosomal 40S subunit, and eIF3. Furthermore elF3 comigrates with IGF2BP1 in $80 S$ ribosomal complexes when a reporter mRNA bearing both the HCV 5'UTR and HCV 3'UTR is translated. Our data suggest that IGF2BP1, by binding to the HCV 5'UTR and/or HCV 3' UTR, recruits eIF3 and enhances HCV IRES-mediated translation.
\end{abstract}

Keywords: HCV-IRES; IGF2BP1; eIF3; translation initiation; HCV-3'UTR; RNA-protein interaction

\section{INTRODUCTION}

$\mathrm{HCV}$, the main causative agent of non-A and non-B hepatitis, belongs to the Flaviviridae family. The plusstrand RNA genome of HCV contains one open-reading frame (ORF) encoding a polyprotein, which is flanked by a 5'UTR and a 3'UTR. These UTRs are conserved between $\mathrm{HCV}$ genotypes and required for viral replication and translation (Binder et al. 2007). Four domains are located in the $5^{\prime} \mathrm{UTR}$, of which domains II to IV form a highly structured IRES that bears an initiator AUG in domain IV

Reprint requests to: Antje Ostareck-Lederer, Clinic of Intensive Care Medicine, Experimental Research Group Intensive Care Medicine, University Hospital Aachen, RWTH Aachen, Pauwelsstrasse 30, 52074 Aachen, Germany; e-mail: aostareck@ukaachen.de; fax: 49 (0)241-803380444; or Dirk Ostareck, Clinic of Intensive Care Medicine, Experimental Research Group Intensive Care Medicine, University Hospital Aachen, RWTH Aachen, Pauwelsstrasse 30, 52074 Aachen, Germany; e-mail: dostareck@ ukaachen.de; fax: 49 (0)241-803380444.

Article published online ahead of print. Article and publication date are at http://www.rnajournal.org/cgi/doi/10.1261/rna.1578409.
(Brown et al. 1992; Reynolds et al. 1996; Kieft et al. 1999). Translation of the polyprotein encoding ORF is initiated by a $5^{\prime}$ cap-independent mechanism at the HCV IRES (Tsukiyama-Kohara et al. 1992; Wang et al. 1993; Reynolds et al. 1996; Pestova et al. 1998). Cell-free translation experiments and reconstitution of HCV IRES-mediated initiation revealed that first a binary complex consisting of the IRES and the ribosomal 40S subunit is constituted at domain III near to the initiator AUG. Secondly, eIF3 and the ternary complex (eIF2/GTP/Met-tRNA $\mathrm{i}^{\mathrm{Met}}$ ) are recruited to form the $43 \mathrm{~S}$ pre-initiation complex, again aided by domain III. Finally, after GTP hydrolysis and eIF2 release, the ribosomal $60 \mathrm{~S}$ subunit joins, and formation of the $80 \mathrm{~S}$ ribosome mediated by domain II and portions of domain III takes place (Pestova et al. 1998; Hellen and Pestova 1999; Ji et al. 2004; Otto and Puglisi 2004). Mutations in the basal part of domain III abolish binding of the ribosomal 40S subunit (Kieft et al. 2001), whereas mutations in the apical loops of domain III affect eIF3 recruitment and $43 \mathrm{~S}$ pre-initiation complex assembly (Ji 
et al. 2004; Otto and Puglisi 2004). Domains II and IV also contact the ribosomal 40S subunit. Domain II interacts with ribosomal protein S5 (Fukushi et al. 2001) and protrudes into the ribosomal start site, causing a conformational change in the ribosomal 40S subunit (Spahn et al. 2001). Proper positioning of the initiation codon is controlled by the sequence (Fletcher et al. 2002) and stability (Honda et al. 1996) of domain IV. Deletion of domain II does not alter the recruitment of eIF3 and the ternary complex, but reduces translational activity fivefold by blocking $80 \mathrm{~S}$ ribosome formation (Pestova et al. 1998; Kolupaeva et al. 2000; Ji et al. 2004; Otto and Puglisi 2004).

The HCV 3'UTR, which lacks a poly(A) tail, is composed of a variable region, a poly(U-C) motif, and a conserved sequence, the $3^{\prime} \mathrm{X}$ region, which forms a structure consisting of three stem-loops (Kolykhalov et al. 1996, 2000; Tanaka et al. 1996; Yamada et al. 1996; Yanagi et al. 1999; Blight et al. 2000; Friebe and Bartenschlager 2002; Yi and Lemon 2003a,b). By transfection of monocistronic reporter RNAs into the human liver-derived cell line Huh7, it has recently been shown that the HCV 3'UTR stimulates translation at the HCV IRES (Song et al. 2006).

Here we address the molecular mechanism for this enhancement. We established an in vitro translation system derived from Huh7 cells and show that the 3'UTR directly stimulates $43 \mathrm{~S}$ pre-initiation complex formation at the HCV 5'UTR. Through the use of the Tob-aptamer technique, we identified IGF2BP1 as a protein, which specifically interacts with both the HCV 5'UTR and HCV 3'UTR. Employing in vitro RNA binding assays, in vitro translation experiments, as well as RNA interference (RNAi) studies, we further characterized the function of IGF2BP1 and show that this protein specifically enhances HCV IRES-mediated translation, but does not affect replication. Interestingly, endogenous IGF2BP1 could be co-immunoprecipitated with the HCV replicon RNA, the ribosomal 40S subunit, and eIF3. Furthermore, eIF3 comigrates with IGF2BP1 in $80 \mathrm{~S}$ ribosomal complexes when a reporter mRNA bearing both the HCV 5'UTR and 3'UTR is translated. Our data implicate that IGF2BP1, by binding to the HCV $5^{\prime} \mathrm{UTR}$ and/or HCV $3^{\prime}$ UTR, recruits eIF3 and enhances HCV IRES-mediated translation. Furthermore, binding of IGF2BP1 to the variable region and the poly(U-C) motif of the HCV $3^{\prime} \mathrm{UTR}$ might facilitate the $5^{\prime}$-to- $3^{\prime}$ interaction of HCV RNA. Both processes can enhance translation at the HCV IRES.

\section{RESULTS}

\section{The HCV RNA 3'UTR stimulates 435 pre-initiation complex formation at the HCV IRES}

To gain more insight in the mechanism of HCV $3^{\prime}$ UTRdependent enhancement of HCV IRES-mediated translation initiation, we established an in vitro translation system based on cytoplasmic extracts of Huh7 cells. This system resembles the $3^{\prime}$ UTR stimulatory effect, which was shown earlier by transfection of monocistronic reporter RNAs into Huh7 cells (Song et al. 2006). The $\left[{ }^{32} \mathrm{P}\right]$ tracelabeled luciferase (LUC) reporter mRNAs bearing the HCV 5'UTR and HCV $3^{\prime}$ UTR (HCV Luc) or no HCV $3^{\prime}$ UTR (HCV $\Delta 3^{\prime}$ UTR Luc) were translated in Huh7 cell extract. Translation rate (Fig. 1A) and mRNA stability (Fig. 1B) were analyzed at $0,15,30$, and $45 \mathrm{~min}$. HCV Luc mRNA translation was stimulated eightfold compared to HCV $\Delta 3^{\prime}$ UTR Luc mRNA after 45 min (Fig. 1A). Reduced Luc expression from the HCV $\Delta 3^{\prime}$ UTR Luc mRNA was not a result of enhanced mRNA degradation as demonstrated by mRNA isolation from the translation reaction (Fig. 1B). These data indicate that the HCV 3'UTR stimulates HCV IRES-mediated translation in vitro.

Next, we aimed to identify the mechanism underlying the enhancing effect of the HCV 3'UTR. To investigate whether or not the initiation step of HCV IRES-mediated translation is augmented by the $3^{\prime}$ UTR, we performed translation initiation reactions, which were analyzed by sucrose gradient centrifugation. To optimize the resolution of translation initiation complexes, we generated shortened reporter mRNAs by replacing the Luc ORF with a synthetic short ORF (sORF) (Fig. 1C). The $\left[{ }^{32} \mathrm{P}\right]$-labeled mRNAs (HCV sORF or HCV $\Delta 3^{\prime}$ UTR sORF) were incubated in translation competent Huh7 cell extract in the presence of cycloheximide, which inhibits the peptidyltransferase reaction and thereby stalls the 80 S ribosome at the AUG (Obrig et al. 1971). Time course experiments from 0.5 to $15 \mathrm{~min}$ revealed that the HCV 3'UTR kinetically enhances $80 \mathrm{~S}$ complex formation (Supplemental Fig. 1A). We further examined these results by a direct comparison of translation initiation reactions performed for 1 and $15 \mathrm{~min}$. After $15 \mathrm{~min}$, 80S complexes did accumulate at the $\mathrm{HCV}$ sORF mRNA, but $80 \mathrm{~S}$ complex formation was reduced at the HCV $\Delta 3^{\prime}$ UTR sORF mRNA (Fig. 1C, cf. left and right panels).

To analyze whether the $3^{\prime} \mathrm{UTR}$ directly enhances $43 \mathrm{~S}$ pre-initiation complex formation, in addition to cycloheximide, the non-hydrolyzable GTP analog GMP-PNP, which stalls $43 \mathrm{~S}$ ribosomal pre-initiation complexes at the initiator AUG, was added (Hershey and Monro 1966; Anthony and Merrick 1992).

After $15 \mathrm{~min}, 43 \mathrm{~S}$ pre-initiation complexes accumulated at the HCV sORF mRNA. In contrast, at the HCV $\Delta 3^{\prime}$ UTR sORF mRNA 43S pre-initiation complex formation was significantly inhibited, demonstrating directly that the $3^{\prime}$ UTR stimulates $43 \mathrm{~S}$ pre-initiation complex assembly (Fig. 1D, cf. left and right panels; Supplemental Fig. 1B).

The position of ribosomal complexes and RNPs in the gradient fractions was analyzed by the distribution of $18 \mathrm{~S}$ and $28 \mathrm{~S}$ rRNA (Fig. 1C,D). $80 \mathrm{~S}$ ribosomes accumulated in fractions 5-8, while fractions 11-14 contained mainly $18 \mathrm{~S}$ rRNA of the ribosomal 40S subunit (Fig. 1C,D, left and right panels). The ribosomal protein rpS3 that is associated 


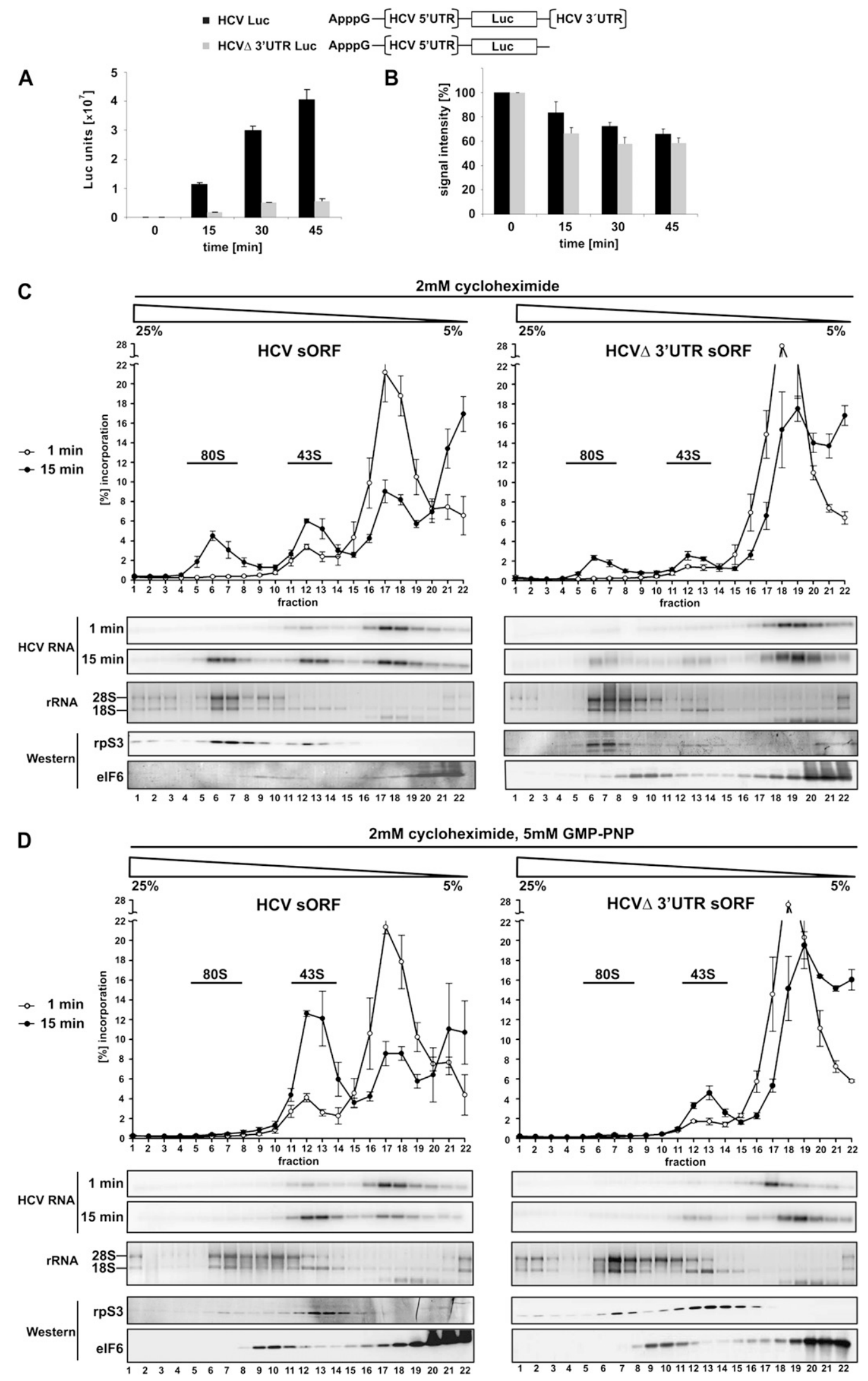

FIGURE 1. (Legend on next page) 
with the ribosomal $40 \mathrm{~S}$ subunit accumulates in $43 \mathrm{~S}$ and $80 \mathrm{~S}$ ribosomal complexes containing fractions (Fig. 1C,D, bottom panel). To localize the position at which the ribosomal $60 \mathrm{~S}$ subunits migrate in the gradient, we analyzed the distribution of eIF6 that is bound to the ribosomal $60 \mathrm{~S}$ subunit prior to $80 \mathrm{~S}$ ribosome formation (Ceci et al. 2003). EIF6 could mainly be detected in fractions 9 and 10 (Fig. 1C,D, bottom panel). These data indicate that the $3^{\prime} \mathrm{UTR}$ stimulates translation initiation by promoting an early step of $80 \mathrm{~S}$ ribosome formation.

\section{Tob-aptamer affinity purification of HCV 5'UTR and 3'UTR complexes from Huh7 cell extract}

Since we observed that the 3'UTR enhances HCV IRESmediated translation initiation, we wanted to analyze the composition of the HCV IRES-associated translation initiation complex assembled on an mRNA bearing both the HCV 5'UTR and HCV 3'UTR. For this purpose, we made use of the Tob-aptamer affinity chromatography. Under physiological conditions, the Tob-aptamer binds with high affinity $\left(K_{\mathrm{D}}=5 \mathrm{nM}\right)$ to the amino glycoside antibiotic tobramycin (Hamasaki et al. 1998). This technique has proved to be highly efficient and specific in the analysis of the pre-spliceosomal protein complex composition (Hartmuth et al. 2002), the HCV RNA-replication complex from Huh7 cell extract (Isken et al. 2007), and HCV IRESassociated $80 \mathrm{~S}$ ribosome complexes from HeLa cell extract (Boehringer et al. 2005).

To purify proteins under translation initiation conditions, we applied the HCV sORF mRNA, which contained the Tob-aptamer upstream of the 5'UTR (Fig. 2A, TobHCV sORF). We first pre-incubated the Tob-HCV sORF mRNA with the tobramycin-affinity matrix to allow efficient mRNA binding. Next the pre-coupled mRNA was incubated with cytoplasmic Huh7 cell extract under translation initiation condition in the presence of cycloheximide. $80 \mathrm{~S}$ ribosomal complex formation was not disturbed by the Tob-aptamer (data not shown). As a specificity control, the RNA bearing no Tob-aptamer (HCV sORF)
(Fig. 2A) or beads alone (data not shown) was used. Proteins specifically eluted from the affinity matrix by tobramycin were analyzed by SDS-PAGE and silver staining (Fig. 2B shows a representative gel). Following extraction and tryptic digestion, liquid chromatography-tandem mass spectrometry was performed to identify the proteins. Only those parts of the Tob-HCV sORF lane in which distinct differences to the control lanes could be detected (Fig. 2B, slices 1-17) were analyzed. Mass spectrometry identified 39 proteins bound to Tob-HCV sORF mRNA. Among others, we found hnRNP C, polypyrimidine tract binding protein 1 , and nucleolin, previously described to interact with the HCV 5'UTR (Gontarek et al. 1999; Ito and Lai 1999; Lu et al. 2004). We also identified NF90/NFAR-1, NF45, and RNA helicase A, which interact with both the HCV 5'UTR and HCV $3^{\prime} \mathrm{UTR}$, and function in HCV replication (Isken et al. 2007).

Interestingly, we also isolated IGF2BP1 that was identified before as an HCV IRES-interacting protein (CRDBP) ( $\mathrm{Lu}$ et al. 2004), but not characterized regarding its function in HCV IRES-mediated translation. A role of IGF2BP1 in the regulation of IGF-II mRNA and $\beta$-actin mRNA translation was described before (Nielsen et al. 1999; Hüttelmaier et al. 2005).

We performed the affinity purification three times and included control purification experiments with an mRNA bearing the HCV 3'UTR, but no HCV 5'UTR (Tob-sORFHCV-3'UTR). When that mRNA was used, besides IGF2BP1, four proteins (NF90/NFAR-1, hnRNP Q, polypyrimidine tract binding protein 1 , and RNA helicase A) were enriched in comparison to the Tob control RNA or beads alone (data not shown).

\section{IGF2BP1 binds to both the HCV 5'UTR and HCV $3^{\prime}$ UTR in vitro}

To analyze the function of IGF2BP1 for HCV IRESmediated translation, we first investigated whether IGF2BP1 directly interacts with the HCV 5'UTR and/or HCV 3'UTR. For this purpose, we performed UV-cross-linking with

FIGURE 1. HCV IRES-mediated translation initiation is enhanced by the HCV 3'UTR in vitro. ( $A, B$, upper panel) Schematic representation of HCV 5'UTR and HCV 3'UTR bearing Luc reporter mRNAs. (Lower panel) Cytoplasmic Huh7 cell extract was used in cell-free translation reactions programmed with the $\left[{ }^{32} \mathrm{P}\right]$ trace-labeled mRNAs HCV Luc or HCV $\Delta 3^{\prime} \mathrm{UTR}$ Luc for the times indicated. Luc activity is expressed as Luc units. Error bars denote the standard deviation from the mean of three different experiments. $\left[{ }^{32} \mathrm{P}\right]$ trace-labeled mRNAs were extracted from the translation reaction at the time points indicated. $\left[{ }^{32} \mathrm{P}\right]$ trace-labeled $5^{\prime}$ cap sORF mRNA was used as an extraction control. Extracted mRNAs were analyzed by agarose gel electrophoresis. The incorporation of $\left[{ }^{32} \mathrm{P}\right]$ was determined by phosphorimaging (Storm 860 Phosphor Imager; Molecular Dynamics, Image Quant software) and expressed as a percentage of signal intensity. Error bars denote the standard deviation from the mean of three different experiments. $(C)\left[{ }^{32} \mathrm{P}\right]$-labeled HCV sORF mRNA (left panel) or HCV $3^{\prime}$ UTR sORF mRNA (right panel) was incubated in Huh7 cell extract in the presence of $2 \mathrm{mM}$ cycloheximide for 1 and $15 \mathrm{~min}$, as indicated. $(D)\left[{ }^{32} \mathrm{P}\right]$-labeled HCV sORF mRNA (left panel) or HCV $\Delta 3^{\prime}$ UTR sORF mRNA (right panel) was incubated in Huh 7 cell extract in the presence of $2 \mathrm{mM}$ cycloheximide and $5 \mathrm{mM}$ GMP-PNP for 1 and $15 \mathrm{~min}$, as indicated. $(C, D)$ Translation initiation complexes were allowed to assemble for the time indicated and subsequently resolved by centrifugation on 5\%-25\% linear sucrose gradients. After fractionation from the bottom to the top of the gradient, the radioactivity was monitored, expressed as a percentage of incorporation, and plotted against the fraction number. RNA extracted from 22 fractions was analyzed on agarose gels and visualized by ethidium bromide staining. The positions of $18 \mathrm{~S}$ and $28 \mathrm{~S}$ rRNA are indicated. The distribution of rpS3 and eIF6 in the sucrose gradient fractions, determined by Western blotting, indicates the position of $80 \mathrm{~S}$ ribosomes and ribosomal $60 \mathrm{~S}$ and $40 \mathrm{~S}$ subunits, respectively. 
A

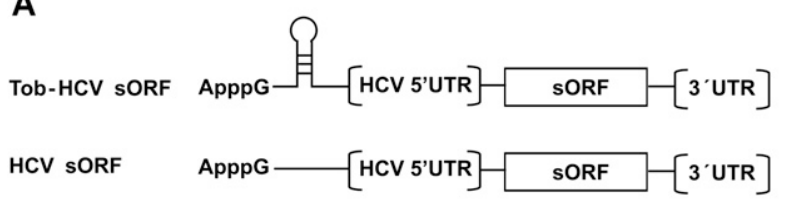

B

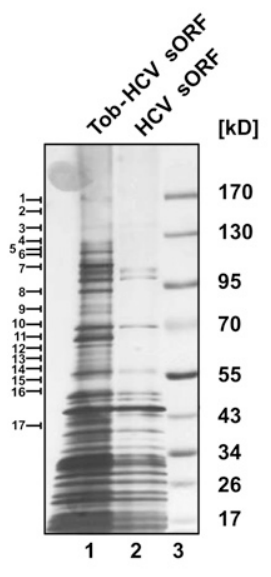

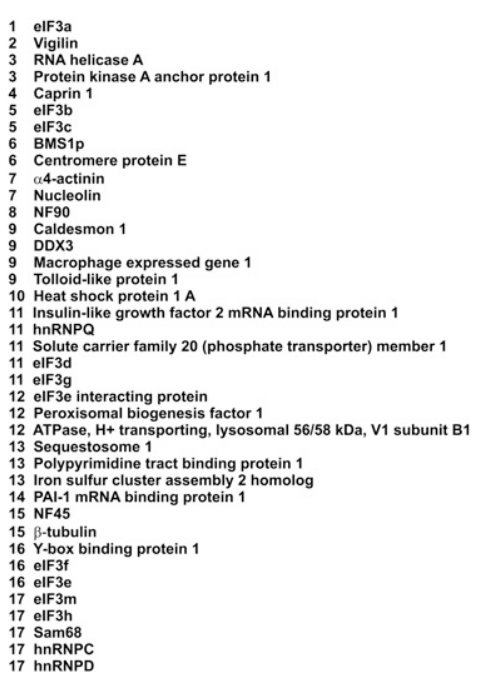

FIGURE 2. Tob-aptamer affinity purification of HCV $5^{\prime} \mathrm{UTR}$ and HCV 3'UTR interacting proteins from cytoplasmic Huh7 cell extract. (A) Schematic representation of the transcripts applied in the RNA affinity purification. ( $B$, left panel) Silver stain of affinity-purified proteins (SDS-PAGE): (lane 1) purification with Tob-HCV sORF; (lane 2) control purification with HCV sORF lacking the Tobaptamer; (lane 3) protein standard. Numbers at the left indicate the position of gel slices used for the identification of proteins shown at the right.

recombinant IGF2BP1 and the $\left[{ }^{32} \mathrm{P}\right]$-labeled $5^{\prime} \mathrm{UTR}$ (nucleotides 1-375) or 3'UTR (nucleotides 1-234) transcripts, respectively (Fig. 3A,B). IGF2BP1 was bound directly to both the 5'UTR (Fig. 3A, lane 1) and 3'UTR (Fig. 3B, lane 1). The nonlabeled $5^{\prime}$ UTR did compete for the interaction of IGF2BP1 with the $5^{\prime}$ UTR (Fig. 3A, lane 3) and the $3^{\prime}$ UTR (Fig. 3B, lane 3). The nonlabeled 3'UTR competed with IGF2BP1 binding as well (Fig. 3A,B, lane 5), but the $5^{\prime}$ leader of the $\beta$-globin mRNA, which served as a negative control, did not affect the interaction (Fig. 3A,B, lanes 6,7). We performed filter binding assays to measure the affinity of IGF2BP1 to the different RNAs (Fig. 3C). IGF2BP1 was bound with nearly the same affinity to the HCV $5^{\prime}$ UTR $(20.5 \mathrm{nM})$ and HCV 3'UTR (18 nM). Consistent with our results in the UV-cross-linking competition assays, the $5^{\prime}$ leader of the $\beta$-globin mRNA showed a significantly weaker affinity for IGF2BP1 (Fig. 3C, $146.70 \mathrm{nM}$ ).

To narrow down the interacting sequence elements, we subdivided the $5^{\prime}$ UTR (375 nt) into three fragments: (1) nucleotides 1-128, consisting of domain I, which contains a short stem-loop and is otherwise mostly single stranded, and domain II, which forms a stem with several internal loops; (2) nucleotides 128-315, representing domain III, a pseudoknot connected to a four-helix junction; and (3) nucleotides 315-375, containing domain IV, in which the HCV IRES AUG-start codon is located. The $3^{\prime}$ UTR (234 nucleotides [nt]) was divided into two fragments: (1) nucleotides 1-151, consisting of the variable region and the poly(U-C) motif; and (2) nucleotides 151-234, which
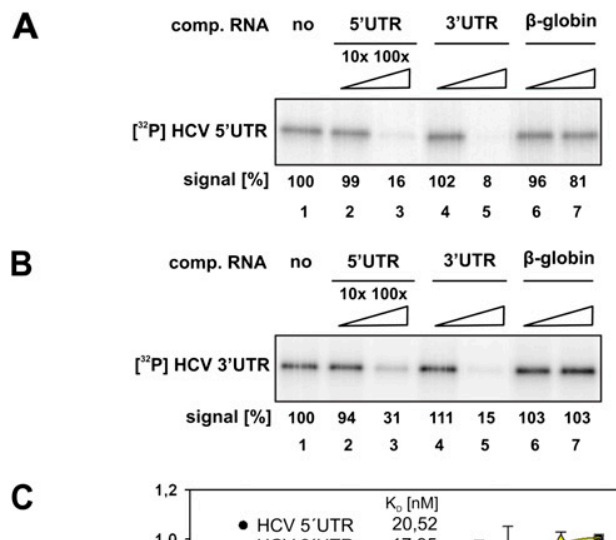

C
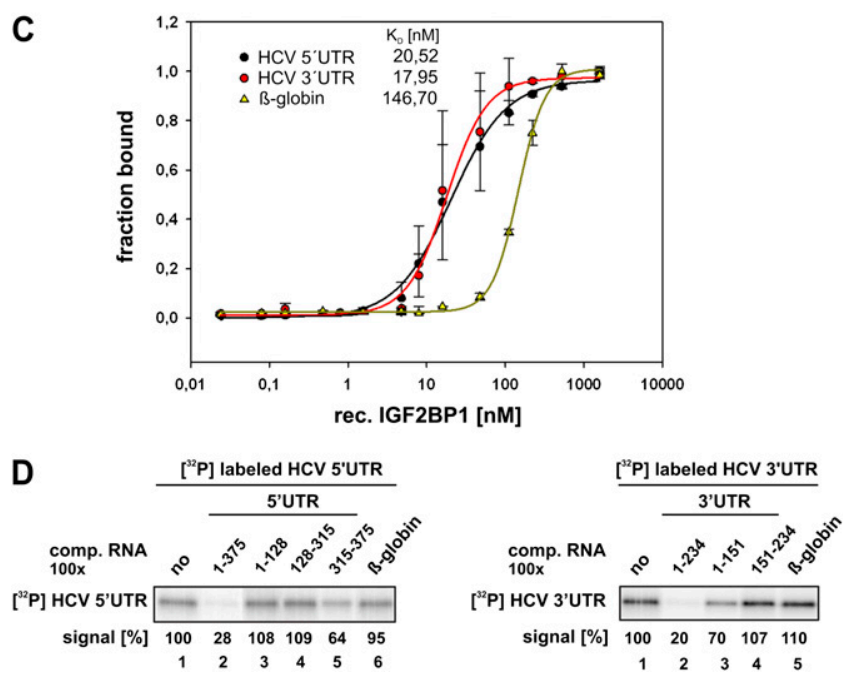

FIGURE 3. IGF2BP1 binds to the HCV $5^{\prime} \mathrm{UTR}$ and $3^{\prime} \mathrm{UTR}$ in vitro. (A) UV-cross-linking of $\left[{ }^{32} \mathrm{P}\right]$-labeled $5^{\prime} \mathrm{UTR}$ and recombinant IGF2BP1 (lane 1) in the presence of 10- or 100-fold molar excess of unlabeled competitor RNAs: (lanes 2,3) 5'UTR; (lanes 4,5) 3'UTR; and (lanes 6,7) $\beta$-globin $5^{\prime}$-leader. (B) UV-cross-linking of $\left[{ }^{32} \mathrm{P}\right]$ labeled 3'UTR and recombinant IGF2BP1 (lane 1) in the presence of 10- or 100-fold molar excess of unlabeled competitor RNAs: (lanes 2,3) 5'UTR; (lanes 4,5) 3'UTR; and (lanes 6,7) $\beta$-globin 5'leader. (C) Filter binding assay performed with $\left[{ }^{32} \mathrm{P}\right]$-labeled (black) HCV 5'UTR; (red) HCV 3'UTR; or (yellow) $\beta$-globin 5'leader and increasing amounts of purified recombinant IGF2BP1. (Inset) $K_{\mathrm{D}}$ values. (D, left panel) UV-cross-linking of $\left[{ }^{32} \mathrm{P}\right]$-labeled $5^{\prime} \mathrm{UTR}$ and recombinant IGF2BP1 (lane 1) in the presence of 100-fold molar excess of unlabeled competitor RNAs: (lane 2) complete 5'UTR (nucleotides 1-375); (lane 3) fragment (1) (nucleotides 1-128); (lane 4) fragment (2) (nucleotides 128-315); (lane 5) fragment (3) (nucleotides 315-375); or (lane 6) $\beta$-globin 5 'leader. (Right panel) UV-cross-linking of $\left[{ }^{32} \mathrm{P}\right]$-labeled $3^{\prime} \mathrm{UTR}$ and recombinant IGF2BP1 (lane 1) in the presence of 100 -fold molar excess of unlabeled competitor RNAs: (lane 2) complete 3'UTR (nucleotides 1-234); (lane 3) fragment (1) (nucleotides 1-151); (lane 4) fragment (2) (nucleotides 151-234); or (lane 5) $\beta$-globin 5 'leader. 
contains the $\mathrm{X}$ region. To determine the binding site in the $5^{\prime}$ UTR in detail, we again performed UV-cross-linking with the $\left[{ }^{32} \mathrm{P}\right]$-labeled $5^{\prime} \mathrm{UTR}$ and added the $5^{\prime} \mathrm{UTR}$ fragments as non-labeled competitor RNAs (Fig. 3D, left panel). The $5^{\prime}$ leader of $\beta$-globin mRNA served as a negative control. Only the complete $5^{\prime}$ UTR and the 5'UTR fragment (3) (nucleotides 315-375) competed with the IGF2BP1-5'UTR interaction (Fig. 3D, left panel, lanes 2,5), while the 5'UTR fragments (1) and (2) and the $5^{\prime}$ leader of $\beta$-globin mRNA had no effect (Fig. 3D, left panel, lanes 3,4,6).

The formation of the IGF2BP1-3'UTR complex was reduced as well, when the complete $3^{\prime} \mathrm{UTR}$ or the $3^{\prime} \mathrm{UTR}$ fragment (1) (nucleotides 1-151) was added (Fig. 3D, right panel, lanes 2,3), while the $3^{\prime}$ UTR fragment (2) (nucleotides $151-234)$ and the $5^{\prime}$ leader of $\beta$-globin mRNA had no effect (Fig. 3D, right panel, lanes 4,5).

From these results, we conclude that IGF2BP1 preferentially binds to stem-loop IV of the $5^{\prime} \mathrm{UTR}$ and to the variable region and the poly $(\mathrm{U}-\mathrm{C})$ motif of the $3^{\prime} \mathrm{UTR}$.

\section{IGF2BP1 is required for HCV IRES-mediated translation, but not for $5^{\prime}$ cap-dependent translation in vivo}

To investigate the specificity of IGF2BP1 for HCV IRESmediated translation, we performed RNAi experiments in Huh7 cells in combination with translation assays (Fig. 4). At the 72-h time point at which the expression of IGF2BP1 was reduced most efficiently employing two independent siRNAs (Fig. 4A, lanes 3,4) in comparison to no siRNA or control siRNA (Fig. 4A, lanes 1,2), we transfected Huh7 cells with in vitro synthesized HCV Luc mRNA, HCV $\Delta 3^{\prime}$ UTR Luc mRNA or a $5^{\prime}$ cap and $3^{\prime}$ poly(A) tail bearing Luc mRNA ( $5^{\prime}$ cap Luc) (Fig. 4B). The contribution of the $3^{\prime}$ UTR was 10 -fold (data not shown), comparable to the eightfold contribution in the in vitro translation system based on Huh7 cells (Fig. 1A). To investigate the effect of the reduced IGF2BP1 level on the $5^{\prime}$ cap-dependent translation and on the contribution of the HCV $3^{\prime}$ UTR simultaneously, the translation of the three mRNAs was set to $100 \%$ in mock transfected cells. In sharp contrast to the 5 'cap-dependent translation that remained unaffected by all transfected siRNAs, the HCV IRES-mediated translation was significantly reduced to $33 \%$ or $26 \%$ by the two independent IGF2BP1 siRNAs (Fig. 4B), which decreased the IGF2BP1 level to $49 \%$ or $40 \%$, respectively (Fig. $4 \mathrm{~A}$ ). The HCV IRES-mediated translation was further reduced to $21 \%$ or $17 \%$, respectively, when the $3^{\prime}$ UTR was lacking (Fig. 4B). Levels of all reporter mRNAs remained unaffected by IGF2BP1 knockdown, as determined by quantitative RT-PCR (Fig. 4C). Hence, changes in Luc reporter mRNA stability were not responsible for the observed specific inhibition of HCV IRES-mediated translation (Fig. $4 \mathrm{~B}, \mathrm{C})$. These results indicate that IGF2BP1 functions specifically in HCV IRES-mediated translation in vivo.
A

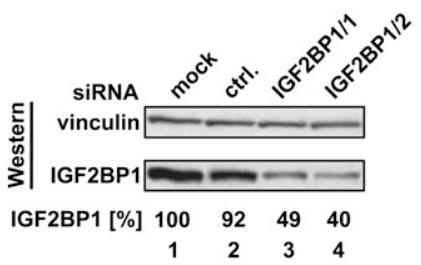

B
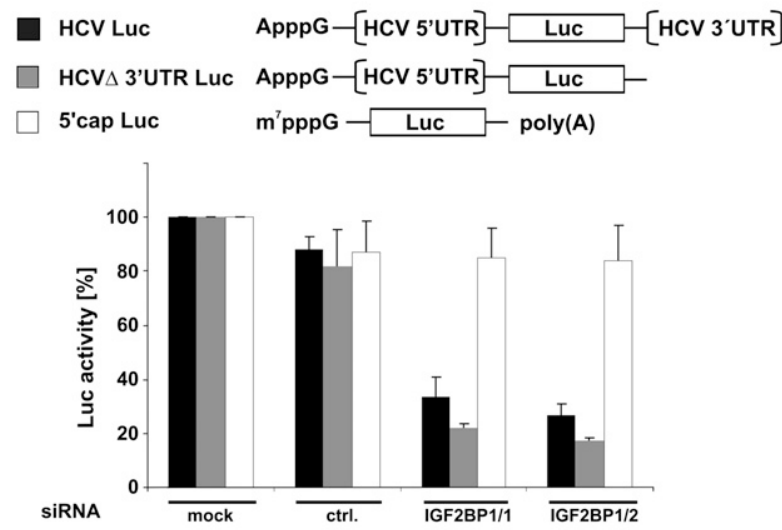

C

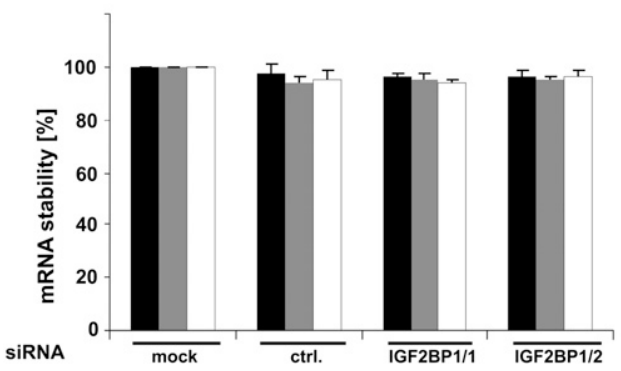

FIGURE 4. IGF2BP1 is required for HCV IRES-mediated translation, but not for 5 'cap-dependent translation in vivo. $(A)$ Huh7 cells were transfected with (lane 1) no siRNA; (lane 2) control siRNA; or (lanes $3,4)$ two independent siRNAs against IGF2BP1. The RNAi effect on protein expression was analyzed using antibodies against IGF2BP1 and vinculin to monitor RNAi specificity. ( $B$, upper panel) Schematic representation of HCV Luc, HCV $\Delta 3^{\prime}$ UTR Luc, and $5^{\prime}$ cap Luc mRNAs. (Lower panel) To quantify the influence of reduced IGFBP1 expression on HCV IRES-mediated or 5'cap-dependent translation, the cells were transfected with the reporter mRNAs indicated. Luc activity was measured and expressed as percentage (average of three experiments with standard deviations). (C) Total RNA was isolated, and the integrity of Luc RNA levels was analyzed by qRT-PCR. Relative RNA amounts were determined by the $\Delta \Delta \mathrm{Ct}$ method using endogenous cyclophilin A mRNA for normalization.

\section{IGF2BP1 enhances HCV IRES-mediated translation initiation in extracts of rat primary hepatocytes}

Employing RNAi, we did not observe a complete reduction of IGF2BP1 with two independent siRNAs ( $49 \%$ or $40 \%$ reduction, respectively) (Fig. 4A); therefore, we used a cell extract that does not contain IGF2BP1 to further study the 3'UTR-dependent mechanism of IGF2BP1 function in HCV IRES-mediated translation. Whereas IGF2BP1 is present in cytoplasmic extract of Huh7 cells, it is not detectable in total or cytoplasmic extracts of rat primary hepatocytes (Fig. 5A, lanes 2-4). We prepared translation 
A

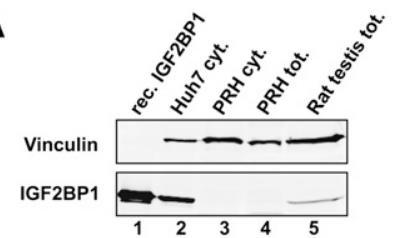

B $\square$ HCV Luc

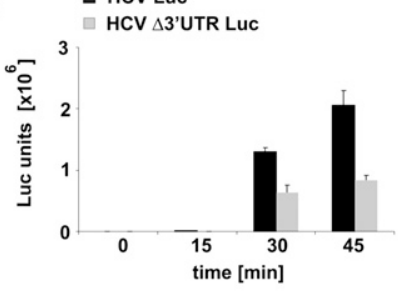

C

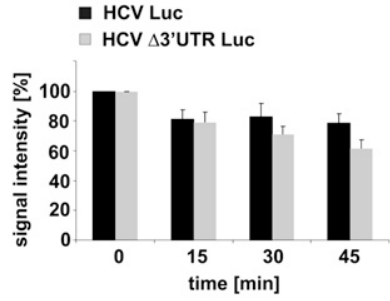

D HCV Luc

- HCV $\triangle 3^{\prime}$ UTR Luc

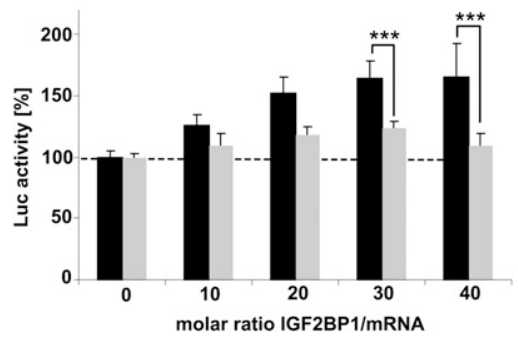

FIGURE 5. IGF2BP1 enhances HCV IRES-mediated translation via the $3^{\prime}$ UTR in rat primary hepatocyte extract. (A) Detection of IGF2BP1 and vinculin (control) in Western blot assays: (lane 1) recombinant IGF2BP1; (lane 2) cytoplasmic Huh 7 cell extract; (lane 3) cytoplasmic rat primary hepatocyte extract; (lane 4) total rat primary hepatocyte extract; and (lane 5) total extract of rat testis (antibody control). (B) Cytoplasmic extract of rat primary hepatocytes was used in cell-free translation reactions, programmed with $\left[{ }^{32} \mathrm{P}\right]$ trace-labeled reporter mRNAs HCV Luc or HCV $\Delta 3^{\prime}$ UTR Luc for the times indicated. Luciferase activity is expressed as relative Luc units. Error bars denote the standard deviation from the mean of three different experiments. $(C)\left[{ }^{32} \mathrm{P}\right]$ trace-labeled mRNAs were extracted from the translation reaction at the time points indicated. $\left[{ }^{32} \mathrm{P}\right]$ trace-labeled 5 'cap sORF mRNA was used as an extraction control. Extracted mRNAs were analyzed by agarose gel electrophoresis. The incorporation of $\left[{ }^{32} \mathrm{P}\right]$ was determined by phosphorimaging (Storm 860 PhosphorImager; Molecular Dynamics Image Quant software) and expressed as a percentage of signal intensity. Error bars denote the standard deviation from the mean of three different experiments. $(D)$ Reporter mRNAs HCV Luc or HCV $\Delta 3^{\prime}$ UTR Luc were incubated in cytoplasmic extracts of rat primary hepatocytes in the presence of increasing amounts of recombinant IGF2BP1. Luciferase activity is expressed as relative Luc units. Error bars denote the standard deviation from the mean of three different experiments. Translation was set to $100 \%$ in the absence of recombinant IGF2BP1. In the presence of recombinant protein, data were analyzed with the $t$-test (twotailed), $\left.{ }^{* * *}\right) p<0.0005$. competent extracts from these primary hepatocytes and analyzed the in vitro translation of $\left[{ }^{32} \mathrm{P}\right]$ trace-labeled reporter mRNAs HCV Luc and HCV $\Delta 3^{\prime}$ UTR Luc for $0,15,30$, and $45 \mathrm{~min}$ (Fig. 5B). Expression from the HCV $\Delta 3^{\prime}$ UTR Luc mRNA was reduced to $0.8 \times 10^{6}$ Luc units after 45 min compared to $2.1 \times 10^{6}$ Luc units from HCV Luc mRNA (Fig. 5B). Notably, both mRNAs were equally stable during translation (Fig. 5C). To investigate the effect of exogenously added IGF2BP1, the translation of both mRNAs was set to $100 \%$ (Fig. 5D). Following addition of increasing amounts of IGF2BP1 to primary hepatocyte extract, only the translation of HCV Luc mRNA was significantly increased, but not translation of $\mathrm{HCV} \Delta 3^{\prime} \mathrm{UTR}$ Luc (Fig. 5D). These results indicate that the interaction of IGF2BP1 with both the HCV 5'UTR and HCV $3^{\prime}$ UTR is required to enhance translation in vitro.

\section{Reduced expression of IGF2BP1 in HCV RNA replicon containing Huh7 cells does not affect HCV RNA replication, but HCV IRES-mediated translation}

Next, we addressed the question whether IGF2BP1, besides affecting HCV IRES-mediated translation, also participates in the viral RNA replication process. For this purpose, we applied Huh7 cells that were stably transfected with an HCV RNA replicon (Lohmann et al. 1999; Grassmann et al. 2005). The HCV RNA replicon is a bi-cistronic, subgenomic viral RNA construct. It encodes a neomycin resistance gene as a selection marker to generate the stable cell line, and the HCV nonstructural proteins NS3, NS4A, NS4B, NS5A, and NS5B that form the viral replicase complex (Fig. 6A). That complex, together with host factors, is capable of replicating the HCV RNA (Lohmann et al. 1999; Grassmann et al. 2005). Translation of the neomycinresistance gene is under the control of the HCV IRES, while the expression of the viral proteins NS3 to NS5B is initiated at the EMCV IRES (Fig. 6A).

First, we investigated the expression level of IGF2BP1 in these cells (Fig. 6B). Interestingly, the IGF2BP1 level was increased more than twofold in the HCV replicon containing Huh7 cells in comparison to naive Huh7 cells as determined by Western blot analysis (Fig. 6B).

Thus, we performed RNAi against IGF2BP1 in Huh7 replicon cells and measured the level of HCV RNA by quantitative RT-PCR. Interestingly, we found that when IGF2BP1 expression was suppressed by RNAi (Fig. 6C, upper panel), no reduction of HCV replication could be observed (Fig. 6C, middle panel). To prove the function of IGF2BP1 for HCV IRES-mediated translation in these cells, we investigated the HCV IRES-mediated expression of neomycin using Western blot assays (Fig. 6C, bottom panel). As a control, we measured the expression of NS5A that is translated via the EMCV IRES. When the expression of IGF2BP1 was reduced by RNAi only neomycin expression was significantly inhibited, but not NS5A 


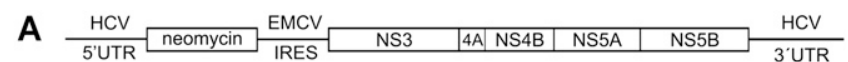

B

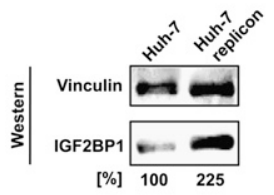

C
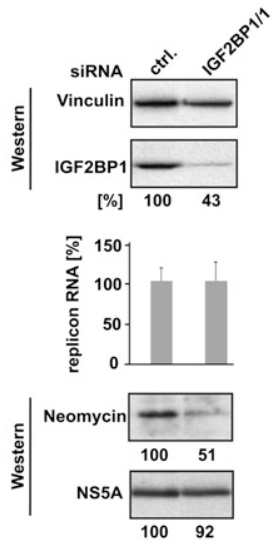

D

E
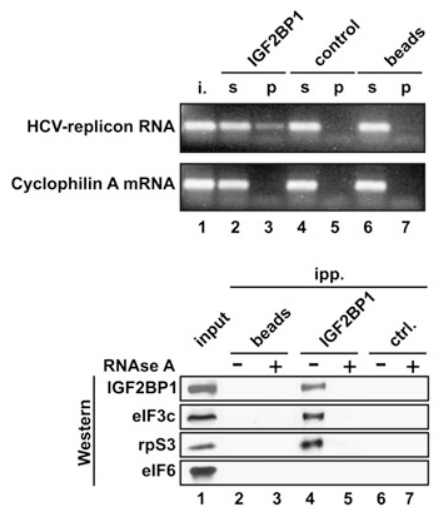

FIGURE 6. Reduced expression of IGF2BP1 in HCV RNA-replicon containing Huh 7 cells does affect HCV IRES-mediated translation, but not HCV RNA replication. (A) Schematic representation of the bi-cistronic replicon RNA. (B) Detection of IGF2BP1 and vinculin (control) in (lane 1) cytoplasmic extracts of Huh7 and (lane 2) Huh7 replicon cells in Western blot assays. $(C)$ Huh7 replicon cells were transfected with (ctrl.) control or (IGF2BP1/1) IGF2BP1 siRNAs. IGF2BP1, vinculin, neomycin phosphotransferase II (NPT2), and NS5A were detected by specific antibodies. HCV RNA replication was measured by qRT-PCR. ( $D$, lane 3 ) IGF2BP1 was immunoprecipitated with a specific IGF2BP1 antibody from cytoplasmic extracts of Huh7 replicon cells. Control immunoprecipitations were performed with (lane 5) a control antibody (Fyn) or (lane 7) beads alone. Coimmunoprecipitated HCV RNA was detected by RT-PCR. Cyclophilin A mRNA served as specificity control. (E) IGF2BP1 was immunoprecipitated with a specific IGF2BP1 antibody from cytoplasmic extracts of Huh7 replicon cells in the (lane 4) absence and (lane 5) presence of RNase A. Control immunoprecipitations were performed with (lanes 2,3) beads alone or (lanes 6,7) a control antibody (Fyn). Immunoprecipitated proteins were resolved on SDS-PAGE and analyzed with antibodies against IGF2BP1, eIF3c, rpS3, or eIF6.

expression (Fig. 6C, bottom panel). From these results we conclude that IGF2BP1 does affect HCV IRES-mediated translation, but not HCV RNA replication.
Since we could detect the inhibition of HCV IRESmediated translation, we next investigated whether endogenous IGF2BP1 interacts with the HCV replicon RNA. Hence, IGF2BP1 was immunoprecipitated from cytoplasmic extract of replicon-transfected cells and, consisting with the purification data (Fig. 2), HCV RNA coprecipitated specifically with the IGF2BP1 antibody, but not with a control antibody or beads alone (Fig. 6D, lanes 3,5,7).

Because IGF2BP1 preferentially interacts with stem-loop IV of the IRES, where also the ribosomal 40S subunit binds (Kieft et al. 1999) and eIF3 enhances the recruitment of the $43 \mathrm{~S}$ preinitiation complex (Pestova et al. 1998), we asked whether IGF2BP1 co-immunoprecipitated with the ribosomal 40S subunit and eIF3, and whether this interaction is RNA-dependent (Fig. 6E). Only in the absence of RNase A we specifically detected rpS3 and eIF3, but not eIF6 (Fig. $6 \mathrm{E}$, lanes 4,5$)$, suggesting that IGF2BP1, by binding to the HCV RNA, facilitates the recruitment of the ribosomal $40 \mathrm{~S}$ subunit and initiation factor eIF3.

\section{eIF3 and IGF2BP1 comigrate with $80 \mathrm{~S}$ ribosomes assembled on HCV 5'UTR and 3'UTR bearing mRNA in Huh7 extract}

To further analyze the specific effect of IGF2BP1 on HCV IRES-mediated, but not $5^{\prime}$ cap-dependent translation (Fig. 4 ), we performed translation initiation reactions in micrococcal nuclease treated Huh7 cell extracts in the presence of cycloheximide comparing $\left[{ }^{32} \mathrm{P}\right]$-labeled $\mathrm{HCV}$ sORF and $5^{\prime}$ cap sORF-poly(A) (5'cap sORF) mRNAs (Fig. 7, left and right panels, respectively). The distribution of $\mathrm{rpS} 3$ indicates the position of $80 \mathrm{~S}$ ribosomes and $43 \mathrm{~S}$ pre-initiation complexes, whereas eIF6 comigrates with ribosomal $60 \mathrm{~S}$ subunits. The distribution of IGF2BP1 between $80 \mathrm{~S}$ ribosome and $43 \mathrm{~S}$ pre-initiation complex containing fractions did not differ significantly between HCV sORF and $5^{\prime}$ cap sORF mRNA besides an additional sedimentation into heavier complexes with $5^{\prime}$ cap sORF mRNA. In contrast, eIF3 comigrated with IGF2BP1 to 80S ribosome containing fractions only when HCV sORF mRNA was translated. These results suggest that IGF2BP1, by binding to the HCV 5'UTR and/or HCV 3'UTR, enhances HCV IRES-mediated translation by recruiting eIF3.

\section{DISCUSSION}

In this study, we demonstrate that the HCV 3'UTR has a strong stimulatory effect on HCV IRES-mediated translation in vitro. A stimulatory effect of the HCV $3^{\prime}$ UTR has been described for transfected monocistronic mRNAs in Huh7 cells (Song et al. 2006). The question of how the HCV RNA 3'UTR enhances translation via the HCV IRES has not been addressed. Employing a newly established in vitro translation system based on Huh7 cell extract that shows a contribution of the HCV 3'UTR to HCV IRES-mediated translation 


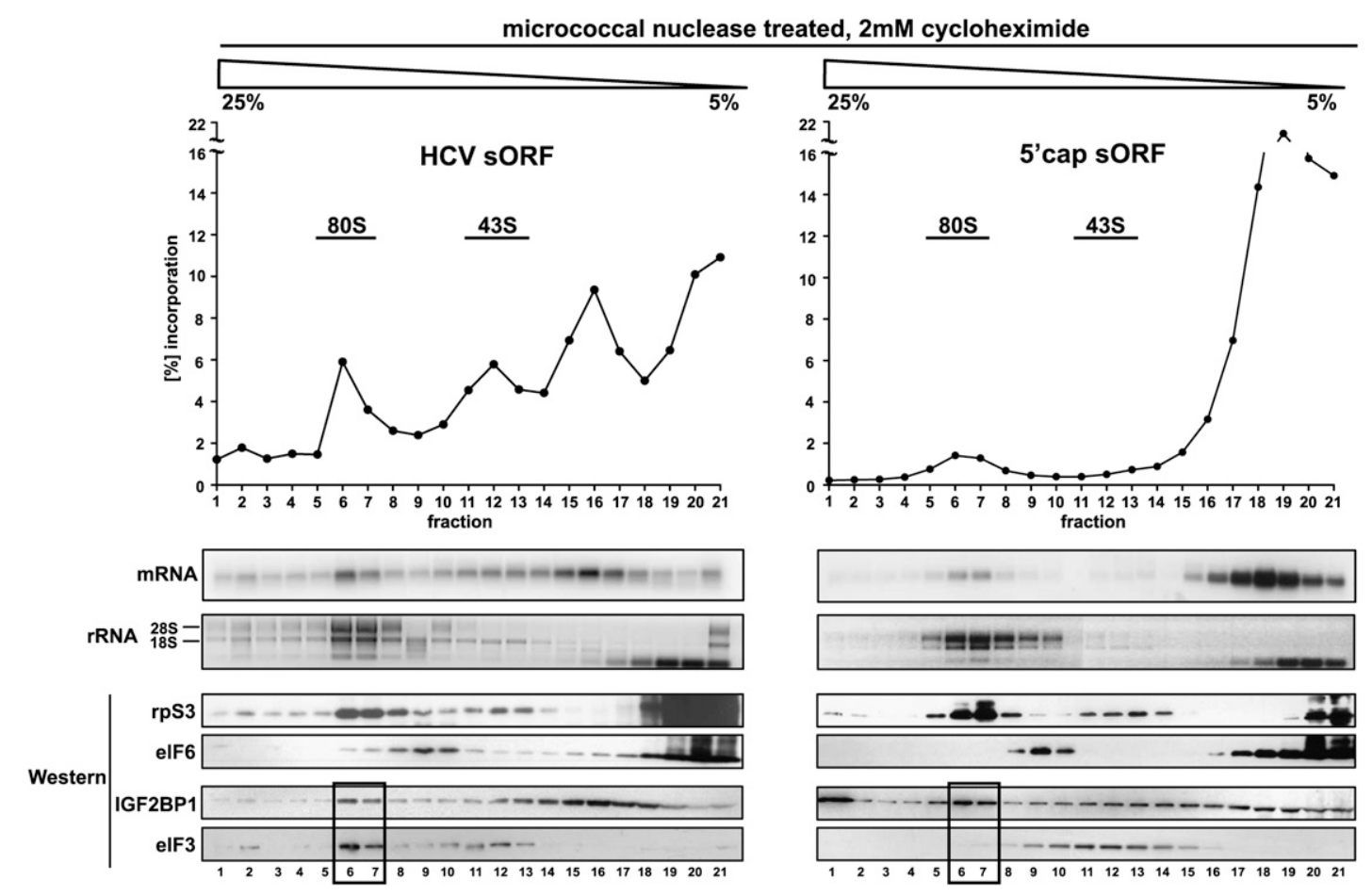

FIGURE 7. eIF3 and IGF2BP1 comigrate with $80 \mathrm{~S}$ ribosomes assembled on HCV $5^{\prime} \mathrm{UTR}$ and $3^{\prime} \mathrm{UTR}$ bearing mRNA in Huh7 extract. [ $\left.{ }^{32} \mathrm{P}\right]-$ labeled (left panel) HCV sORF mRNA or (right panel) 5'cap sORF mRNA was incubated in micrococcal nuclease treated Huh7 cell extract in the presence of $2 \mathrm{mM}$ cycloheximide for $15 \mathrm{~min}$. $(A, B)$ Translation initiation complexes were allowed to assemble and subsequently resolved by centrifugation on 5\%-25\% linear sucrose gradients. After fractionation from the bottom to the top of the gradient, the radioactivity was monitored, expressed as the percentage of incorporation, and plotted against the fraction number. The distribution of rpS3, eIF6, IGF2BP1, or eIF3c in the sucrose gradient fractions was determined using specific antibodies.

(Fig. 1A,B), we investigated the underlying mechanism. We show that 80 S complex assembly is stimulated by the HCV 3'UTR on an HCV IRES-bearing mRNA; hence the 3'UTR enhances translation initiation. Our data reveal that the $3^{\prime}$ UTR promotes translation initiation at an early step by increasing the recruitment of $43 \mathrm{~S}$ pre-initiation complexes (Fig. 1C,D). To shed light on the molecular requirements for the enhancing function of the $3^{\prime} \mathrm{UTR}$, we adapted the Tob-aptamer RNA chromatography combined with liquid chromatography-tandem mass spectrometry to identify factors that interact with the HCV $5^{\prime}$ UTR and/or HCV 3'UTR and contribute to the increased translation initiation at the HCV IRES in translational active Huh7 cell extract (Fig. 2). By using an mRNA that bears both the HCV 5'UTR and HCV 3'UTR as an affinity matrix, we specifically purified proteins that have been shown to interact with either the HCV 5'UTR or HCV $3^{\prime}$ UTR, or both. The proteins IGF2BP1, hnRNP C, hnRNP $\mathrm{D}$, hnRNP Q, polypyrimidine tract binding protein 1, PAI-1 mRNA binding protein 1, nucleolin, NF90/NFAR, RNA helicase A, and five subunits of eIF 3 (out of nine identified) match with proteins isolated from cytoplasmic Huh7 cell extract employing an HCV 5'UTR that lacks domain I and represents the HCV IRES consisting of domains II to IV (Kim et al. 2004; Lu et al. 2004). HnRNP
C, YB-1, polypyrimidine tract binding protein 1, DDX3, NF90/NFAR, and RNA helicase A have been identified as HCV 3'UTR binding proteins in Huh7 extract (Gontarek et al. 1999; Harris et al. 2006; Isken et al. 2007). Only for some of these interactions has a functional relevance been shown. The impact of NF90/NFAR, NF45, and RNA helicase A on HCV RNA replication has been characterized by Isken et al. (2007). An enhancement of HCV IRESmediated initiation by hnRNP Q has been described by $\mathrm{Kim}$ et al. (2004). The function of polypyrimidine tract binding protein 1 in HCV IRES-mediated translation is controversially discussed (Ali and Siddiqui 1995; Ito and Lai 1999; Ostareck-Lederer et al. 2005; Brocard et al. 2007).

In our study, we evaluated the function of IGF2BP1 for HCV IRES-mediated translation. IGF2BP1 belongs to a family of RNA binding proteins, also termed IGF-II mRNA binding proteins (IMPs), zipcode mRNA binding proteins (ZBPs), or coding region instability determinant binding proteins (CRDBPs), which are involved in the regulation of RNA localization, translation, and turnover (Yisraeli 2005). Members of that protein family are expressed early in development, strongly decline in the postnatal phase, but show de novo synthesis in neoplasias (Nielsen et al. 1999; Yaniv and Yisraeli 2002; Kobel et al. 2007). 
It has been shown that IGF2BP1 controls the translation of $\beta$-actin mRNA and IFG-II mRNA. In the case of IGF-II mRNA association of IGF2BP1 with the 5'UTR is suggested to be a prerequisite of translation inhibition (Nielsen et al. 1999). In contrast $\beta$-actin mRNA translation is blocked by IGF2BP1 binding to the $3^{\prime} \mathrm{UTR}$. That interaction mediates translation inhibition at a late step of initiation at the 5'UTR (Hüttelmaier et al. 2005).

Our purified complex also shares proteins, which are common to IGF2BP1 granules, purified from human embryonic kidney 293 cells (HEK293) and human bone osteosarcoma epithelial cells (U2OS), like RNA helicase A, nucleolin, hnRNP Q, hnRNP D, and YB-1 (Jønson et al. 2007; Weidensdorfer et al. 2009).

Employing RNA-protein interaction techniques, we show that recombinant IGF2BP1 specifically interacts with both, the HCV 5'UTR and the 3'UTR (Fig. 3). This interaction is in the lower nanomolar range as shown for the binding of IGF2BP1 to the zipcode motif that has been identified as the binding region in the $\beta$-actin mRNA 3'UTR (Farina et al. 2003). We could not identify a distinct sequence element, like the zipcode motif, in either UTR. For the tau mRNA 3'UTR, it was shown that IGF2BP1 does not recognize a specific mRNA sequence, but a threedimensional structure (Atlas et al. 2007). Furthermore, IGF2BP1 (CRDBP) (Doyle et al. 1998) binds to the CRD region located in the last $249 \mathrm{nt}$ of the c-myc coding sequence, which has closely been defined to nucleotides 1763-1777 (Coulis et al. 2000). The CRD has some similarity with the zipcode (ACACCC) (Ross et al. 1997) and the IGF2BP1-binding consensus sequence (UUCACGUU CACA) (Nielsen et al. 1999), but no common motif required for RNA binding is defined.

The competition studies suggest that the HCV 5'UTR fragment that represents domain IV of the HCV IRES, but not domains I-III, is the major site of interaction. In the $3^{\prime} \mathrm{UTR}$, the variable region and poly(U-C) motif contribute to IGF2BP1 binding (Fig. 3).

To investigate the specificity of the IGF2BP1 function in HCV IRES-mediated translation in vivo RNAi against IGF2BP1 was performed in Huh7 cells. While control siRNA has no effect on HCV IRES-mediated and 5'capdependent Luc expression, a reduction of IGF2BP1 does result in a specific decrease of HCV IRES-mediated Luc expression, which was further reduced in the absence of the 3'UTR and had no impact on 5'cap-dependent translation (Fig. 4). This suggests that IGF2BP1 has a specific function on HCV IRES-mediated translation and is not a general translational regulator. The incomplete reduction of $\mathrm{HCV}$ IRES-mediated Luc translation might not only be due to the limited IGF2BP1 knockdown, but could also be a result of compensatory effects of other IGF2BP isoforms. Although we have only identified IGF2BP1 in the affinity purification assay, two other members of the IGF2BP family (IGF2BP2 and IGF2BP3) are present in Huh7 cells.
Furthermore, we have purified several HCV 5'UTR and HCV 3'UTR interacting proteins (YB-1, nucleolin, hnRNP C, hnRNP D). Besides the significant impact of IGF2BP1 on HCV IRES-mediated translation, these factors might also play a role. This was shown for the stability of the c-myc mRNA that is regulated by an IGF2BP1-associated cytoplasmic RNP consisting of hnRNP U, syncrip (hnRNP Q), YB-1, and DHX9 (Weidensdorfer et al. 2009). A focus of further studies will be the function of other identified factors in the context of IGF2BP1. Interestingly, compared to an individual IGF2BP1 knockdown, a double knockdown with one of the additional factors shows no additive effect on the stability of c-myc mRNA. This suggests that stabilization is likely to occur via one regulatory complex (Weidensdorfer et al. 2009).

By employing an in vitro translation system generated from primary hepatocytes, which do not express IGF2BP1, the requirement of both the HCV 5'UTR and 3'UTR for efficient HCV IRES-mediated translation can be demonstrated. When the extract is supplemented with recombinant IGF2BP1, the translation of an mRNA that bears the HCV 5'UTR and HCV 3'UTR is enhanced in contrast to an mRNA, which lacks the HCV 3'UTR (Fig. 5). The observed intensity of this effect might be due to the fact that we added recombinant IGF2BP1, which showed a high affinity binding to the HCV 5'UTR and HCV 3'UTR (Fig. 3C), but possibly IGF2BP1 has to be modified post-translationally in order to enhance HCV IRES-mediated translation. Furthermore, IGF2BP1 has several mRNA targets (Yisraeli 2005) and might act in different cellular complexes concurrently. Therefore, the protein that is added can be incorporated in other functional complexes, which limits the impact on HCV Luc mRNA translation.

Because in HCV infected cells translation of the plusstrand RNA HCV genome precedes replication, we investigated whether IGF2BP1 supports the replication of a bicistronic reporter RNA stably expressed in Huh7 cells (Fig. 6). We first noticed a twofold increased IGF2BP1 level in the Huh7 replicon cells. This might be due to an activation of phosphoinositide 3-kinase mediated by the nonstructural HCV protein NS5A, which leads to the stabilization of $\beta$-catenin, resulting in an increased $\beta$-catenin dependent transcription of the IGF2BP1 gene (Street et al. 2005; Gu et al. 2008). Interestingly, the knockdown of IGF2BP1 resulted in an inhibition of the HCV IRES-mediated translation, but did not influence replication. In contrast, knockdown of RNA helicase A, DDX5, or HuR, which interact with the HCV 5'UTR and/or HCV 3'UTR, resulted in a reduced replication (Harris et al. 2006; Isken et al. 2007). For hnRNP Q, an influence on HCV IRES-mediated translation and HCV replication has been shown (Kim et al. 2004; Liu et al. 2009).

To get an initial insight into how IGF2BP1 specifically functions on HCV IRES-mediated translation, we performed immunoprecipitation experiments and found that 
IGF2BP1 specifically coprecipitates with eIF3 and rpS3, a component of the ribosomal $40 \mathrm{~S}$ subunit, in an RNA dependent manner (Fig. 6E). Furthermore, it colocalizes specifically with eIF3 in $80 \mathrm{~S}$ ribosome containing fractions when an mRNA bearing both the HCV 5'UTR and HCV $3^{\prime}$ UTR is translated (Fig. 7, cf. left and right bottom panels).

This could explain why only HCV IRES-mediated translation, but not 5'cap-dependent translation, is inhibited when the expression of IGF2BP1 is reduced (Fig. 4). EIF3 increases $43 \mathrm{~S}$ pre-initiation complex formation and is required for $80 \mathrm{~S}$ ribosome formation on the HCV IRES (Pestova et al. 1998; Sizova et al. 1998). IGF2BP1 bound to the HCV 5'UTR and/or HCV 3'UTR might enhance HCV IRES-mediated translation by recruiting eIF3. Furthermore, the interaction of IGF2BP1 with both UTRs can support mRNA circularization because the protein has been shown to dimerize upon RNA binding (Nielsen et al. 2004).

It will be interesting to study in the future whether, together with the recruitment of eIF3, the dimerization facilitates an increase in translation as it was shown for the formation of a closed loop structure and a synergistic interplay between the 5'cap and the 3'poly(A) tail (Gallie 1991; Jacobson 1996; Wells et al. 1998; Amrani et al. 2008).

\section{MATERIALS AND METHODS}

\section{Plasmids}

All plasmid constructs used for in vitro transcription of $\mathrm{HCV}$ RNAs derive from the plasmid HCVwt-fLuc-3'UTR (HCV Luc) or the plasmid HCVwt-fLuc (HCV $\Delta 3^{\prime} \mathrm{UTR}$ Luc), which contain genomic sequences of Hepatitis $\mathrm{C}$ genotype $1 \mathrm{~b}$ encoding the UTRs and the firefly luciferase ORF (Ostareck-Lederer et al. 2005). The plasmids HCV sORF and HCV $\Delta 3^{\prime}$ UTR sORF were generated from HCV Luc and HCV $\Delta 3^{\prime}$ UTR Luc by replacing the luciferasecoding sequence by a Flag-tag sequence between Hind III and BamHI (Supplemental Table). Tob-HCV sORF was generated by cloning the J6f1 aptamer (Tob) (Hartmuth et al. 2002; Jiang and Patel 2004) into KpnI upstream of the HCV 5'UTR in the plasmid HCV sORF (Isken et al. 2007). The sequences from the HCV 5'UTR and HCV 3'UTR used in the UV-cross-linking assay were generated by subcloning them into pBSII SK (Stratagene). The HCV 5'UTR fragment (1) was generated using KpnI and SmaI, fragment (2) using SmaI, and fragment (3) using SmaI and Hind III. The HCV 3'UTR was separated into fragments (1) and (2) using DdeI. The $\beta$-globin $5^{\prime}$ leader ( $\beta$-globin) (Hellen et al. 1993) was subcloned into pBSII SK using XhoI. CAT control RNA (pGEMCAT) and $5^{\prime}$ cap sORF poly(A) have been described by Naarmann et al. (2008); the latter was linearized with XhoI to generate a poly(A) tail. The $5^{\prime}$ cap Luc-poly(A) have been described by Iizuka et al. (1994). GST-ZBP1 in pGEX6P1 (Amersham) was used for expression of recombinant IGF2BP1 (Hüttelmaier et al. 2005).

\section{Cell culture and cytoplasmic extract preparation}

Huh7 cells and Huh7 replicon cells were grown in Dulbecco's Modified Eagle's Medium supplemented with 10\% fetal bovine serum (FBS; Biochrom), 1\% non-essential amino acids, and $1 \%$ penicillin streptomycin (Invitrogen). Rat primary hepatocytes prepared according to Seglen (1976) were a kind gift of M. Sgodda and $\mathrm{H}$. Aurich (Martin-Luther-University Halle-Wittenberg). Huh7 S10 extract was prepared according to Barton and Flanegan (1993). Briefly, $1 \times 10^{8}$ of subconfluent Huh7 cells were harvested using Trypsin-EDTA (Invitrogen), washed three times with 10 volumes of isotonic buffer ( $35 \mathrm{mM} \mathrm{HEPES/KOH}$ at $\mathrm{pH} 7.6,146$ $\mathrm{mM} \mathrm{NaCl}, 11 \mathrm{mM}$ glucose) and collected by centrifugation at $220 \mathrm{~g}$. The pellet was resuspended in 1.5 volumes of hypotonic buffer [20 mM HEPES/KOH at $\mathrm{pH} 7.6,10 \mathrm{mM} \mathrm{KCl}, 1.5 \mathrm{mM}$ $\mathrm{Mg}\left(\mathrm{CH}_{3} \mathrm{CO}_{2}\right)_{2}, 1 \mathrm{mM}$ DTT, protease inhibitors] and incubated for $20 \mathrm{~min}$ on ice. The cells were broken with 25 strokes in a dounce homogenizer, and 0.2 volumes of $5 \times \mathrm{S} 10$ buffer [100 $\mathrm{mM} \mathrm{HEPES} / \mathrm{KOH}$ at $\mathrm{pH} 7.6,600 \mathrm{mM} \mathrm{K}\left(\mathrm{CH}_{3} \mathrm{CO}_{2}\right)_{2}, 20 \mathrm{mM}$ $\mathrm{Mg}\left(\mathrm{CH}_{3} \mathrm{CO}_{2}\right)_{2}, 25 \mathrm{mM}$ DTT, protease inhibitors] were added. Nuclei were removed by centrifugation at $10.000 \mathrm{~g}$ for $10 \mathrm{~min}$ at $4^{\circ} \mathrm{C}$. Aliquots of the extract were stored at $-80^{\circ} \mathrm{C}$.

\section{Protein expression and purification}

Expression of recombinant IGF2BP1 was performed according to Farina et al. (2003) with the following modifications: BL21 (DE3) cells were induced for $4 \mathrm{~h}$ at $23^{\circ} \mathrm{C}$ with $1 \mathrm{mM}$ IPTG in minimal medium $\left(72 \mathrm{mM} \mathrm{Na}_{2} \mathrm{HPO}_{4} \times 7 \mathrm{H}_{2} \mathrm{O}, 22 \mathrm{mM} \mathrm{KH} \mathrm{PO}_{4}, 8.5 \mathrm{mM}\right.$ $\mathrm{NaCl}, 18.7 \mathrm{mM} \mathrm{NH} \mathrm{m}_{4} \mathrm{Cl}, 0.4 \%$ casamino acids, $11 \mathrm{mM}$ Glucose, 1 $\mathrm{mM} \mathrm{MgSO}_{4}, 0.3 \mathrm{mM} \mathrm{CaCl}$ ). Bacteria were lysed in lysis buffer (PBS, 1\% Triton X-100, $850 \mathrm{mM} \mathrm{NaCl}, 10 \mathrm{mM}$ EDTA, $10 \mathrm{mM}$ EGTA, 1:1000 $\beta$-mercaptoethanol, protease inhibitors). After sonication the lysate was cleared for $30 \mathrm{~min}$ at $8000 \mathrm{~g}$ at $4^{\circ} \mathrm{C}$. Glutathione Sepharose beads 4B (GE Healthcare) were incubated with the cleared lysate for $1.5 \mathrm{~h}$ at $4{ }^{\circ} \mathrm{C}$. After washing, the GST tag was cleaved with precision protease (GE Healthcare) in $50 \mathrm{mM}$ Tris (pH 7.6), $300 \mathrm{mM} \mathrm{NaCl}, 1 \mathrm{mM} \mathrm{EDTA}$, and $3 \mathrm{mM}$ $\beta$-mercaptoethanol, protease inhibitors overnight at $4^{\circ} \mathrm{C}$. Next the protein was loaded onto a HiTrap Heparin HP column (GE Healthcare) in binding buffer $\left(50 \mathrm{mM} \mathrm{Na}_{2} \mathrm{HPO}_{4}, 25 \mathrm{mM} \mathrm{NaCl}\right.$ at $\mathrm{pH}$ 7.2) and eluted in $50 \mathrm{mM} \mathrm{Na}_{2} \mathrm{HPO}_{4}, 1 \mathrm{M} \mathrm{NaCl}$ (pH 7.2). Purified fractions were pooled and desalted into storage buffer (20 $\mathrm{mM}$ HEPES at $\mathrm{pH} 7.6,150 \mathrm{mM} \mathrm{NaCl}, 10 \%$ glycerol) via PD-10 columns (Amersham) and stored at $-80^{\circ} \mathrm{C}$. Protein concentrations were determined by the BCA assay (Thermo Scientific), SDS-PAGE, and Coomassie staining using bovine serum albumin as a standard.

\section{In vitro transcription}

RNAs were transcribed with a T7 MEGAscript Kit (Applied Biosystems/Ambion) according to the manufacturer's instructions using $7 \mathrm{mM}$ ApppG-cap (KEDAR). RNAs were purified by phenol and phenol/chloroform extraction, filtration (Chromaspin-100 column, Takara), and ethanol precipitation and quantified spectrometrically. For tobramycin-affinity coupling reactions, in vitro translation assays, UV-cross-linking assays, filter binding assays, and sucrose density gradient analysis, the RNAs were labeled with $10-30 \mu \mathrm{Ci} \alpha-\left[{ }^{32} \mathrm{P}\right]$ UTP $(3000 \mathrm{Ci} / \mathrm{mmol}, 10 \mathrm{mCi} / \mathrm{mL}$; Hartmann Analytic). RNA yield was determined by Čerenkov counting.

\section{Tobramycin affinity purification}

The tobramycin affinity purification was carried out as described by Isken et al. (2007) with the following modifications: 28 pmol of 
Tob-HCV sORF or HCV sORF were precoupled to the tobramycinmatrix for $1.5 \mathrm{~h}$ by rotation at $4^{\circ} \mathrm{C}$ in $400 \mu \mathrm{L}$ of binding buffer (BB) $\left(20 \mathrm{mM}\right.$ Tris- $\mathrm{HCl}$ at $\mathrm{pH} 8.1,1 \mathrm{mM} \mathrm{CaCl}, 1 \mathrm{mM} \mathrm{MgCl}_{2}$, $0.2 \mathrm{mM}$ DTT), and the matrix was washed three times in $\mathrm{BB}$. Translation initiation reactions $(400 \mu \mathrm{L})$ containing $2 \mathrm{mM}$ cycloheximide were loaded onto the matrix and incubated for $30 \mathrm{~min}$ at $30^{\circ} \mathrm{C}$. Subsequently, the matrix was washed three times in $\mathrm{BB}$, supplemented with $75 \mathrm{mM} \mathrm{KCl}$ and $5 \mathrm{mM} \mathrm{MgCl}_{2}$. Bound complexes were eluted with $250 \mu \mathrm{L}$ of $\mathrm{BB}$, supplemented with $5 \mathrm{mM}$ tobramycin, $145 \mathrm{mM} \mathrm{KCl}$, and $2 \mathrm{mM} \mathrm{MgCl}_{2}$ for $30 \mathrm{~min}$ by rotation at room temperature (RT). Proteins were recovered by methanol-chloroform precipitation (Jiang et al. 2004) and analyzed by $5 \%-15 \%$ SDS-PAGE and silver staining (Shevchenko et al. 1996).

\section{Mass spectrometry}

Protein bands were cut out, washed, and digested with trypsin (Promega) in $30 \mu \mathrm{L}$ of $10 \mathrm{mM}$ ammonium bicarbonate $(\mathrm{pH} 8.0)$ overnight at $37^{\circ} \mathrm{C}$ (Shevchenko et al. 1996). Tryptic peptides were extracted, and liquid chromatography-tandem mass spectrometry (LC/MS/MS) analyses were performed using a Micromass CapLC column $75 \mu \mathrm{m} \times 15 \mathrm{~cm}, 3 \mu \mathrm{m}$ dC18 Atlantis NanoEase (Waters) coupled to a quadrupole time-of-flight mass spectrometer (QTOF2; Micromass). Peptide fragment ion spectra were searched against the non-redundant protein database for exact matches using MASCOT (http://www.matrixscience.com).

\section{UV cross-linking}

For UV cross-linking, 0.5 or 5 pmol of competitor RNA were preincubated for $15 \mathrm{~min}$ at $30^{\circ} \mathrm{C}$ with $1.6 \mu \mathrm{M}$ recombinant IGF2BP1, $1 \mu \mathrm{g}$ of rRNA (Escherichia coli) in $10 \mathrm{mM}$ HEPES ( $\mathrm{pH} 7.6), 100$ $\mathrm{mM} \mathrm{KCl}, 2 \mathrm{mM} \mathrm{MgCl}, 5 \%$ glycerol, $1 \mathrm{mM} \mathrm{DTT}$, and $40 \mathrm{U}$ RNasin (Promega). Fifty fmoles of $\left[{ }^{32} \mathrm{P}\right]$-labeled RNA (specific activity: $10.000 \mathrm{cpm} / \mathrm{pmol}$ ) were added and incubated for $15 \mathrm{~min}$. After addition of $5.5 \mu \mathrm{g}$ of heparin, the samples were exposed to ultraviolet light $(254 \mathrm{~nm})$ for $10 \mathrm{~min}$ at $4^{\circ} \mathrm{C}$ followed by treatment with $7 \mu \mathrm{g}$ of RNase A and $20 \mathrm{U}$ of RNase $\mathrm{T} 1$ for $60 \mathrm{~min}$ at $37^{\circ} \mathrm{C}$. Proteins were analyzed by $12 \%$ SDS-PAGE and autoradiography.

\section{Filter binding}

A $40 \mu \mathrm{L}$ binding reaction contained $50 \mathrm{mM}$ Tris $(\mathrm{pH} 8.0), 100$ $\mathrm{mM} \mathrm{KCl,} 1 \mathrm{mM}$ EDTA $0.5 \mathrm{mM}$ DTT, $10 \%$ glycerol, $0.2 \mathrm{mg} / \mathrm{mL}$ BSA, $0.01 \%$ Ipegal, $5 \mathrm{fmol}$ of $\left[{ }^{32} \mathrm{P}\right]$-labeled RNA (specific activity: $500.000 \mathrm{cpm} / \mathrm{pmol})$, and increasing amounts $(0.7 \mathrm{pM}$ to $1.6 \mu \mathrm{M})$ of recombinant IGFBP1. After $10 \mathrm{~min}$ of incubation at RT, the reactions were applied to cellulose nitrate membrane filters (NC 20, $0.2 \mu \mathrm{m}$; Whatman) and washed in $50 \mathrm{mM}$ Tris ( $\mathrm{pH} 8.0), 100$ $\mathrm{mM} \mathrm{KCl}$, and $1 \mathrm{mM}$ EDTA. The filter-bound radioactivity was measured by scintillation counting. Apparent $K_{\mathrm{D}}$ values were calculated using nonlinear regression applied by SigmaPlot.

\section{In vitro translation}

Translation reactions contained $40 \%$ Huh7 S10 or rat primary hepatocyte extract, $100 \mu \mathrm{M}$ amino acids, $16 \mathrm{mM}$ HEPES ( $\mathrm{pH} 7.6$ ), 2-3 mM $\mathrm{Mg}\left(\mathrm{CH}_{3} \mathrm{CO}_{2}\right)_{2}, 100-160 \mathrm{mM} \mathrm{KCH} \mathrm{CO}_{2}, 80 \mu \mathrm{g} / \mathrm{mL}$ tRNA, $0.8 \mathrm{mM}$ ATP, $0.1 \mathrm{mM}$ GTP, $40 \mu \mathrm{g} / \mathrm{mL}$ creatine kinase, 20 $\mathrm{mM}$ creatine phosphate, and $70-350 \mathrm{fmol}$ of $\left[{ }^{32} \mathrm{P}\right]$ trace-labeled
HCV reporter mRNAs. Translation reactions were incubated up to $45 \mathrm{~min}$ at $37^{\circ} \mathrm{C}$ and stopped on ice. Luciferase activity was measured using the luciferase assay system (Promega) in a tube Luminometer (Berthold Technologies).

\section{Sucrose gradient analysis}

Huh7 cell extract was incubated with $560 \mathrm{fmol}$ of $\left[{ }^{32} \mathrm{P}\right]$-labeled $\mathrm{HCV}$ RNA in the presence of $2 \mathrm{mM}$ cycloheximide (SigmaAldrich) and $5 \mathrm{mM}$ GMP-PNP (Jena Biosciences) for the indicated time points at $30^{\circ} \mathrm{C}$. Translation initiation complexes were resolved on linear 5\%-25\% sucrose density gradients (prepared in $20 \mathrm{mM}$ HEPES at pH 7.6, $150 \mathrm{mM} \mathrm{KCH}_{3} \mathrm{CO}_{2}, 5 \mathrm{mM}$ $\mathrm{MgCl}_{2}, 1 \mathrm{mM} \mathrm{DTT}$ ) by centrifugation at $100,000 \mathrm{~g}$ for $225 \mathrm{~min}$. Fractions ( $500 \mu \mathrm{L}$ each) were collected from the bottom to the top of the gradient and analyzed by Čerenkov counting. For RNA analysis, $400 \mu \mathrm{L}$ of each fraction were extracted with Trizol (Invitrogen) and separated on a $1 \%$ agarose gel. For protein analysis, $400 \mu \mathrm{L}$ of each fraction were methanol-chloroform precipitated (Jiang et al. 2004), separated on a 5\%-18\% SDS gradient PAGE, and analyzed by Western blot assay.

\section{Micrococcal nuclease treatment}

To remove endogenous RNAs, Huh7 extract was micrococcal nuclease-treated prior to the translation reaction. Four microliters of Huh7 extract were treated with $0.08 \mathrm{U}$ of micrococcal nuclease (Roche) and $0.8 \mathrm{mM} \mathrm{CaCl}_{2}$ for $15 \mathrm{~min}$ at $27^{\circ} \mathrm{C}$. The reaction was stopped with $1.6 \mathrm{mM}$ EGTA and used for in vitro translation.

\section{Antibodies and Western blotting}

The monoclonal antibody against IGF2BP1/ZBP1 has been described by Hüttelmaier et al. (2005). All other antibodies were purchased from Santa Cruz Biotechnologies (eIF3c, sc-28858, Fyn, sc-434), Abnova (eIF2S1, H00001965-M01), BD Transduction Laboratories (eIF6, 611120), NEB (rpS3, 2579S), Sigma-Aldrich (vinculin, V9131), and Abcam (Neomycin phosphotransferase II, ab 60018). NS5A antiserum has been described by Isken et al. (2007). HRP conjugated secondary antibodies were purchased from GE Healthcare (NA931; NA934), infrared fluorescence labeled antibodies (926-32212; 926-32223) from LI-COR Biosciences.

PVDF membrane (Fisher Scientific) was blocked in 5\% milk, 2\% BSA, TBST (5 mM Tris- $\mathrm{HCl}$ at $\mathrm{pH} 7.4,10 \mathrm{mM}$ Glycin, 300 $\mathrm{mM} \mathrm{NaCl}, 0.1 \%$ Tween 20) for $1 \mathrm{~h}$ at RT. Antibodies were incubated according to the manufacturer's instructions. HRPconjugated antibodies (1:3000) were incubated for $1 \mathrm{~h}$ at RT, and membranes were developed with ECL Western blotting substrate (Thermo Scientific) or infrared antibodies (1:10.000) for $30 \mathrm{~min}$ at RT following visualization with an LI-COR infrared scanner (Odyssey software).

\section{RNAi}

Huh7 or Huh7 replicon cells $\left(0.6 \times 10^{6}\right.$ cells in Dulbecco's Modified Eagle's Medium without FBS and antibiotics) were transfected by electroporation ( $270 \mathrm{~V}, 950 \mu \mathrm{F}$, GenePulser II; Bio-Rad) with 500 pmol of IGF2BP1 siRNA or 500 pmol of nonspecific control siRNA (Supplemental Table 1) (MWG-Biotechnology). Cells were harvested 24-72 h post-transfection for Western blot 
assays. Cell pellets were lysed in RIPA buffer $(50 \mathrm{mM}$ Tris- $\mathrm{HCl}$ at $\mathrm{pH} 7.5,150 \mathrm{mM} \mathrm{NaCl}, 1 \%$ Ipegal, $0.5 \%$ sodiumdesoxycholate, protease inhibitors) for $15 \mathrm{~min}$ on ice following $10 \mathrm{~min}$ of centrifugation at $10,000 \mathrm{~g}$ at $4^{\circ} \mathrm{C}$. Protein concentration was determined by BCA assay (Thermo Scientific).

\section{RNA transfection}

Seventy-two hours after siRNA transfection, $1 \times 10^{6}$ Huh-7 cells were transfected in cytomix containing $1.25 \%$ DMSO (van den Hoff et al. 1992) by electroporation with 17.5 pmol of reporter mRNAs, and harvested after $3 \mathrm{~h}$. Cells were counted and washed twice in PBS ( $137 \mathrm{mM} \mathrm{NaCl}, 2.7 \mathrm{mM} \mathrm{KCl}, 10 \mathrm{mM} \mathrm{Na}_{2} \mathrm{HPO}_{4}$, and

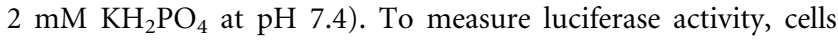
were resuspended in luciferase lysis reagent (Promega). RNA stability was analyzed by quantitative RT-PCR.

\section{Quantitative RT-PCR}

Total RNA was extracted using Trizol (Invitrogen). For reverse transcription, random primers and $2 \mu \mathrm{g}$ of RNA (Fig. 4C) or oligo(dT) primers and $0.5 \mu \mathrm{g}$ RNA (Fig. 6C), or specific primers (Luciferase, HCV replicon, cyclophilin A) (see Supplemental Table 1), M-MLV RT (Fermentas) were used. QRT-PCR was performed using SYBRgreen (Taq-Master mix; Promega) in an MX3000p cycler (Stratagene). RNA amounts were determined by the $\Delta \Delta C_{t}$ method using cyclophilin A mRNA for internal normalization (Livak and Schmittgen 2001).

\section{Immunoprecipitation}

Twenty microliters of protein A-sepharose coupled with $1.5 \mu \mathrm{g}$ of IGF2BP1 or Fyn antibody were incubated with $50 \mu \mathrm{g}$ of Huh7 replicon S10 extract for $4 \mathrm{~h}$ at $4^{\circ} \mathrm{C}$ in $\mathrm{BB}(20 \mathrm{mM}$ HEPES at $\mathrm{pH}$ 7.6, $100 \mathrm{mM} \mathrm{KCl,} 5 \mathrm{mM} \mathrm{MgCl}$, 0.5\% Ipegal, $1 \mathrm{mM}$ DTT, RNasin, protease inhibitors). Beads were washed twice with $\mathrm{BB}$ and boiled in SDS sample buffer. The supernatant was analyzed in Western blot assays. RNase A treatment $(20 \mu \mathrm{g} / \mathrm{mL})$ was performed during the last washing step in BB for $15 \mathrm{~min}$ at RT. For RT-PCR, coimmunoprecipitated RNA in the pellet was isolated with Trizol (Invitrogen). For RT, equal volumes of RNA, random primers (Promega), a HCV replicon specific primer, and $150 \mathrm{U}$ of M-MLV-RT (Promega) were used. Aliquots $(2 \mu \mathrm{L})$ of the reverse transcription were used for PCR with GoTaq-FlexiDNA polymerase (Promega) and the respective primer pairs (Supplemental Table 1).

\section{SUPPLEMENTAL MATERIAL}

Supplemental material can be found at http://www.rnajournal.org.

\section{ACKNOWLEDGMENTS}

We thank M. Sgodda and H. Aurich for preparation of the rat primary hepatocytes, R. Geißler for the measurements of the replicon RNA by qRT-PCR, and N. Flach for technical assistance. This work was supported by the Network Biosciences SachsenAnhalt (FCA TP1) and a Heisenberg Fellowship (OS 290/1-2) of the Deutsche Forschungsgemeinschaft (to A.O.-L.).

Received January 27, 2009; accepted April 28, 2009.

\section{REFERENCES}

Ali N, Siddiqui A. 1995. Interaction of polypyrimidine tract-binding protein with the $5^{\prime}$ noncoding region of the Hepatitis $\mathrm{C}$ virus RNA genome and its functional requirement in internal initiation of translation. J Virol 69: 6367-6375.

Amrani N, Ghosh S, Magnus DA, Jacobson A. 2008. Translation factors promote the formation of two states of the closed-loop mRNP. Nature 453: 1276-1280.

Anthony D, Merrick WC. 1992. Analysis of $40 \mathrm{~S}$ and $80 \mathrm{~S}$ complexes with mRNA as measured by sucrose density gradients and primer extension inhibition. J Biol Chem 267: 1554-1562.

Atlas R, Behar L, Sapoznik S, Ginzburg I. 2007. Dynamic association with polysomes during P19 neuronal differentiation and an untranslated-region-dependent translation regulation of the $\tau$ mRNA by the $\tau$ mRNA-associated proteins IMP1, HuD, and G3BP1. J Neurosci Res 85: 173-183.

Barton DJ, Flanegan JB. 1993. Coupled translation and replication of poliovirus RNA in vitro: Synthesis of functional 3D polymerase and infectious virus. J Virol 67: 822-831.

Binder M, Quinkert D, Bochkarova O, Klein R, Kezmic N, Bartenschlager R, Lohmann V. 2007. Identification of determinants involved in initiation of Hepatitis C virus RNA synthesis by using intergenotypic replicase chimeras. J Virol 81: 5270-5283.

Blight KJ, Kolykhalov AA, Rice CM. 2000. Efficient initiation of HCV RNA replication in cell culture. Science 290: 1972-1974.

Boehringer D, Thermann R, Ostareck-Lederer A, Lewis JD, Stark H. 2005. Structure of the Hepatitis C virus IRES bound to the human 80 S ribosome: Remodeling of the HCV IRES. Structure 13: 16951706.

Brocard M, Paulous S, Komarova AV, Deveaux V, Kean KM. 2007. Evidence that PTB does not stimulate HCV IRES-driven translation. Virus Genes 35: 5-15.

Brown EA, Zhang H, Ping LH, Lemmon SM. 1992. Secondary structure of the $5^{\prime}$ nontranslated regions of Hepatitis $C$ virus and pestivirus genomic RNAs. Nucleic Acids Res 20: 5041-5045.

Ceci M, Gaviraghi C, Gorrini C, Sala LA, Offenhäuser N, Marchisio PC, Biffo S. 2003. Release of eIF6 (p27BBP) from the 60S subunit allows $80 \mathrm{~S}$ ribosome assembly. Nature 426: 579-584.

Coulis CM, Lee C, Nardone V, Prokipcak RD. 2000. Inhibition of c-myc expression in cells by targeting an RNA-protein interaction using antisense oligonucleotides. Mol Pharmacol 57: 485-494.

Doyle GA, Betz NA, Leeds PF, Fleisig AJ, Prokipcak RD, Ross J. 1998. The c-myc coding region determinant-binding protein: A member of a family of KH domain RNA-binding proteins. Nucleic Acids Res 26: $5036-5044$.

Farina KL, Huttelmaier S, Musunuru K, Darnell R, Singer RH. 2003. Two ZBP1 KH domains facilitate $\beta$-actin mRNA localization, granule formation, and cytoskeletal attachment. J Cell Biol 160: 77-87.

Fletcher SP, Ali IK, Kaminski A, Digard P, Jackson RJ. 2002. The influence of the viral coding sequence on pestivirus IRES activity reveals further parallels with translation initiation in prokaryotes. RNA 8: 1558-1571.

Friebe P, Bartenschlager R. 2002. Genetic analysis of sequences in the 3 'nontranslated region of Hepatitis $\mathrm{C}$ virus that are important for RNA replication. J Virol 76: 5326-5338.

Fukushi S, Okada M, Stahl J, Kageyama T, Hoshino FB, Katayama K. 2001. Ribosomal protein S5 interacts with the internal ribosome entry site of the Hepatitis C virus. J Biol Chem 276: 20824-20826.

Gallie DR. 1991. The cap and poly(A) tail function synergistically to regulate mRNA translational efficiency. Genes \& Dev 5: 2108-2116.

Gontarek RR, Gutshall LL, Herold KM, Tsai J, Sathe GM, Mao J, Prescott C, Del Vecchio AM. 1999. hnRNP C and polypyrimidine tract-binding protein specifically interact with the pyrimidine-rich region within the $3^{\prime}$ NTR of the HCV RNA genome. Nucleic Acids Res 27: 1457-1463.

Grassmann CW, Yu H, Isken O, Behrens SE. 2005. Hepatitis C virus and the related bovine viral diarrhea virus considerably differ in 
the functional organization of the $5^{\prime}$ nontranslated region: Implications of the viral life cycle. Virology 333: 349-366.

$\mathrm{Gu}$ W, Wells AL, Pan F, Singer RH. 2008. Feedback regulation between zipcode binding protein 1 and $\beta$-catenin mRNAs in breast cancer cells. Mol Cell Biol 28: 4963-4974.

Hamasaki K, Killian J, Cho J, Rando RR. 1998. Minimal RNA constructs that specifically bind aminoglycoside antibiotics with high affinities. Biochemistry 37: 656-663.

Harris D, Zhang Z, Chaubey B, Pandey VN. 2006. Identification of cellular factors associated with the $3^{\prime}$-nontranslated region of the Hepatitis C virus genome. Mol Cell Proteomics 5: 1006-1018.

Hartmuth K, Urlaub H, Vornlocher HP, Will CL, Gentzel M, Wilm M, Lührmann R. 2002. Proetin composition of human prespliceosomes isolated by a tobramycin affinity selection method. Proc Natl Acad Sci 99: 16719-16724.

Hellen CU, Pestova TV. 1999. Translation of Hepatitis C virus RNA. $J$ Viral Hepat 6: 79-87.

Hellen CU, Witherell GW, Schmid M, Shin SH, Pestova TV, Gil A, Wimmer E. 1993. A cytoplasmic $57-\mathrm{kDA}$ protein that is required for translation of picornavirus RNA by internal ribosomal entry is identical to the nuclear pyrimidine tract-binding protein. Proc Natl Acad Sci 90: 7642-7646.

Hershey JW, Monro RE. 1966. A competitive inhibitor of the GTP reaction in protein synthesis. J Mol Biol 18: 68-76.

Honda M, Brown EA, Lemmon SM. 1996. Stability of a stem-loop involving the initiator AUG controls the efficiency of internal initiation of translation on Hepatitis C virus RNA. RNA 2: 955968.

Hüttelmaier S, Zenklusen D, Lederer M, Dictenberg J, Lorenz M, Meng X, Bassell GJ, Condeelis J, Singer RH. 2005. Spatial regulation of $\beta$-actin translation by src-dependent phosphorylation of ZBP1. Nature 438: 512-515.

Iizuka N, Najita L, Franzusoff A, Sarnow P. 1994. Cap-dependent and cap-independent translation by internal initiation of mRNAs in cell extracts prepared from Saccharomyces cerevisiae. Mol Cell Biol 14: $7322-7330$.

Isken O, Baroth $\mathrm{M}$, Grassmann $\mathrm{CW}$, Weinlich S, Ostareck DH, Ostareck-Lederer A, Behrens SE. 2007. Nuclear factors are involved in Hepatitis C virus RNA replication. RNA 13: 16751692.

Ito T, Lai MM. 1999. An internal polypyrimidine-tract-binding protein-binding site in the Hepatitis $\mathrm{C}$ virus RNA attenuates translation, which is relieved by the $3^{\prime}$-untranslated sequence. Virology 254: 288-296.

Jacobson A. 1996. Poly(A) metabolism and translation: The closed loop model. In Translational control (eds. JW Hershey et al.), pp. 451-480. Cold Spring Harbor Laboratory Press, Cold Spring Harbor, NY.

Ji H, Fraser CS, Yu Y, Leary J, Doudna JA. 2004. Coordinated assembly of human translation initiation complexes by the Hepatitis C virus internal ribosome entry site RNA. Proc Natl Acad Sci 101: 16990-16995.

Jiang L, Patel DJ. 2004. Solution structure of the tobramycin-RNA aptamer complex. Nat Struct Biol 5: 769-774.

Jiang L, He L, Fountoulakis M. 2004. Comparison of protein precipitation methods for sample preparation prior to proteomic analysis. J Chromatogr A 1023: 317-320.

Jønson L, Vikesaa J, Krogh A, Nielsen LK, Hansen T, Borup R, Johnsen AH, Christiansen J, Nielsen FC. 2007. Molecular composition of IMP1 ribonucleoprotein granules. Mol Cell Proteomics 6: 798-811.

Kieft JS, Zhou K, Jubin R, Murray MG, Lau JY, Doudna JA. 1999. The Hepatitis C virus internal ribosome entry site adopts an iondependent tertiary fold. J Mol Biol 292: 513-529.

Kieft JS, Zhou K, Jubin R, Doudna JA. 2001. Mechanism of ribosome recruitment by Hepatitis C IRES RNA. RNA 7: 194-206.

Kim JH, Paek KY, Ha SH, Cho S, Choi K, Kim CS, Ryu SH, Jang SK. 2004. A cellular RNA-binding protein enhances internal ribosomal entry site-dependent translation through an interaction down- stream of the Hepatitis $\mathrm{C}$ virus polyprotein initiation codon. $\mathrm{Mol}$ Cell Biol 24: 7878-7890.

Kobel M, Weidensdorfer D, Reinke C, Lederer M, Schmitt WD, Zeng K, Thomssen C, Hauptmann S, Hüttelmaier S. 2007. Expression of the RNA-binding protein IMP1 correlates with poor prognosis in ovarian carcinoma. Oncogene 26: 7584-7589.

Kolupaeva VG, Pestova TV, Hellen CU. 2000. An enzymatic footprinting analysis of the interaction of $40 \mathrm{~S}$ ribosomal subunits with the internal ribosomal entry site of Hepatitis C virus. J Virol 74: $6242-6250$.

Kolykhalov AA, Feinstone SM, Rice CM. 1996. Identification of a highly conserved sequence element at the 3 ' terminus of Hepatitis C virus genome RNA. J Virol 70: 3363-3371.

Kolykhalov AA, Mihalik K, Feinstone SM, Rice CM. 2000. Hepatitis C virus-encoded enzymatic activities and conserved RNA elements in the $3^{\prime}$ nontranslated region essential for virus replication in vivo. J Virol 74: 2046-2051.

Liu HM, Aizaki H, Choi KS, Machida K, Ou JJ, Lai MM. 2009. SYNCRIP (synaptotagmin-binding, cytoplasmic RNA-interacting protein) is a host factor involved in Hepatitis C virus RNA replication. Virology 386: 249-256.

Livak KJ, Schmittgen TD. 2001. Analysis of relative gene expression data using real-time quantitative PCR and the $2^{-\Delta \Delta \mathrm{C}(\mathrm{T})}$. Methods 25: 402-408.

Lohmann V, Korner F, Koch J, Herian U, Theilmann L, Bartenschlager R. 1999. Replication of subgenomic Hepatitis C virus RNA in a hepatoma cell line. Science 285: 110-113.

Lu H, Li W, Noble WS, Payan D, Anderson DC. 2004. Riboproteomics of the Hepatitis C virus internal ribosomal entry site. J Proteome Res 3: 949-957.

Naarmann IS, Harnisch C, Flach N, Kremmer E, Kühn H, Ostareck DH, Ostareck-Lederer A. 2008. mRNA silencing in human erythroid cell differentiation: Heterogeneous nuclear ribonucleoprotein $\mathrm{K}$ controls the expression of its regulator c-Src. J Biol Chem 283: 18461-18472.

Nielsen J, Christiansen J, Lykke-Andersen J, Johnsen AH, Wewer UM, Nielsen FC. 1999. A family of insulin-like growth factor II mRNAbinding proteins represses translation in late development. Mol Cell Biol 19: 1262-1270.

Nielsen J, Kristensen MA, Willemoes M, Nielsen FC, Christiansen J. 2004. Sequential dimerization of human zipcode-binding protein IMP1 on RNA: A cooperative mechanism providing RNP stability. Nucleic Acids Res 32: 4368-4376.

Obrig TG, Culp WJ, Mckeehan WL, Hardesty B. 1971. The mechanism by which cycloheximide and related glutarimide antibiotics inhibit peptide synthesis on reticulocyte ribosomes. J Biol Chem 246: 174-181.

Ostareck-Lederer A, Clauder-Münster S, Thermann R, PolycarpouSchwarz M, Gentzel M, Wilm M, Lewis JD. 2005. The role of RNA interference in drug target validation: Application to Hepatitis C. In RNA Interference: From basic science to drug development (ed. K Appasani), pp. 318-330. Cambridge University Press, Cambridge, UK.

Otto GA, Puglisi JD. 2004. The pathway of HCV IRES-mediated translation initiation. Cell 119: 369-380.

Pestova TV, Shatsky IN, Fletcher SP, Jackson RJ, Hellen CU. 1998. A prokaryotic-like mode of cytoplasmic eukaryotic ribosome binding to the initiation codon during internal translation initiation of Hepatitis C and classical swine fever virus RNAs. Genes \& Dev 12: 67-83.

Reynolds JE, Kaminski A, Carroll AR, Clarke BE, Rowlands DJ, Jackson RJ. 1996. Internal initiation of translation of Hepatitis C virus RNA: The ribosome entry site is at the authentic initiation codon. RNA 2: 867-878.

Ross AF, Oleynikov Y, Kislauskis EH, Taneja KL, Singer RH. 1997. Characterization of a $\beta$-actin mRNA zipcode-binding protein. Mol Cell Biol 17: 2158-2165.

Seglen PO. 1976. Preparation of isolated rat liver cells. Methods Cell Biol 13: 29-83. 
Shevchenko A, Wilm M, Vorm O, Mann M. 1996. Mass spectrometric sequencing of proteins silver-stained polyacrylamide gels. Anal Chem 68: 850-858.

Sizova DV, Kolupaeva VG, Pestova TV, Shatsky IN, Hellen CUT. 1998. Specific interaction of eukaryotic translation initiation factor 3 with the $5^{\prime}$ nontranslated region of Hepatitis $\mathrm{C}$ virus and classical swine fever virus RNAs. J Virol 72: 4775-4782.

Song $\mathrm{Y}$, Friebe $\mathrm{P}$, Tzima $\mathrm{E}$, Jünemann $\mathrm{C}$, Bartenschlager $\mathrm{R}$, Niepmann M. 2006. The Hepatitis C virus RNA 3'-untranslated region strongly enhances translation directed by the internal ribosome entry site. J Virol 80: 11579-11588.

Spahn CM, Kieft JS, Grassucci RA, Penczek PA, Zhou K, Doudna JA, Frank J. 2001. Hepatitis C virus IRES RNA-induced changes in the conformation of the 40S ribosomal subunit. Science 291: 1959-1962.

Street A, Macdonald A, McCormick C, Harris M. 2005. Hepatitis C virus NS5A-mediated activation of phosphoinositide 3-kinase results in stabilization of cellular $\beta$-catenin and stimulation of $\beta$-catenin-responsive transcription. J Virol 79: 5006-5016.

Tanaka TN, Kato N, Cho MJ, Sugiyama K, Shimotohno K. 1996. Structure of the $3^{\prime}$ terminus of the Hepatitis $\mathrm{C}$ virus genome. $J$ Virol 70: 3307-3312.

Tsukiyama-Kohara K, Iizuka N, Kohara M, Nomoto A. 1992. Internal ribosome entry site within Hepatitis C virus RNA. J Virol 66: 1476-1483.

van den Hoff MJ, Moorman AF, Lamers WH. 1992. Electroporation in 'intracellular' buffer increases cell survival. Nucleic Acids Res 20: 2902.
Wang C, Sarnow P, Siddiqui A. 1993. Translation of human Hepatitis $\mathrm{C}$ virus RNA in cultured cells is mediated by an internal ribosomebinding mechanism. J Virol 67: 3338-3344.

Weidensdorfer D, Stöhr N, Baude A, Lederer M, Köhn M, Schierhorn A, Buchmeier S, Wahle E, Hüttelmaier S. 2009. Control of c-myc mRNA stability by IGF2BP1-associated cytoplasmic RNPs. RNA 15: 104-115.

Wells SE, Hillner P, Vale R, Sachs AB. 1998. Circularization of mRNA by eukaryotic translation initiation factors. Mol Cell 2: 135-140.

Yamada N, Tanihara K, Takada A, Yorihuzi T, Tsutsumi M, Shimomura H, Tsuji T, Date T. 1996. Genetic organization and diversity of the $3^{\prime}$ noncoding region of the Hepatitis $\mathrm{C}$ virus genome. Virology 223: 255-261.

Yanagi M, St Claire M, Emerson SU, Purcell RH, Bukh J. 1999. In vivo analysis of the $3^{\prime}$ untranslated region of the Hepatitis $\mathrm{C}$ virus after in vitro mutagenesis of an infectious cDNA clone. Proc Natl Acad Sci 96: 2291-2295.

Yaniv K, Yisraeli JK. 2002. The involvement of a conserved family of RNA binding proteins in embryonic development and carcinogenesis. Gene 287: 49-54.

Yi M, Lemon SM. 2003a. 3' nontranslated RNA signals required for replication of Hepatitis C virus RNA. J Virol 77: 3557-3568.

Yi M, Lemon SM. 2003b. Structure-function analysis of the 3' stemloop of Hepatitis $\mathrm{C}$ virus genomic RNA and its role in viral RNA replication. RNA 9: 331-345.

Yisraeli JK. 2005. VICKZ proteins: A multi-talented family of regulatory RNA-binding proteins. Biol Cell 97: 87-96. 

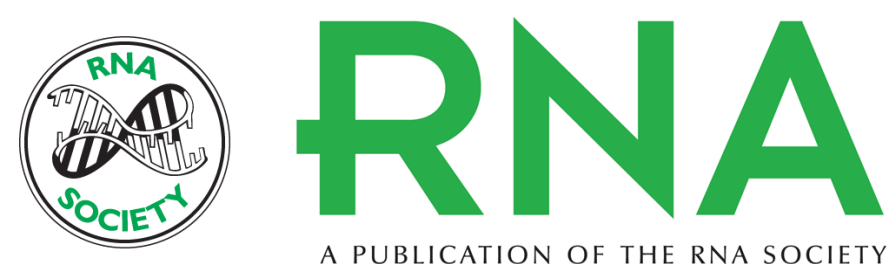

A PUBLICATION OF THE RNA SOCIETY

\section{IGF2BP1 enhances HCV IRES-mediated translation initiation via the 3' UTR}

Susan Weinlich, Stefan Hüttelmaier, Angelika Schierhorn, et al.

RNA 2009 15: 1528-1542 originally published online June 18, 2009

Access the most recent version at doi:10.1261/rna.1578409

\section{Supplemental http://rnajournal.cshlp.org/content/suppl/2009/06/19/rna.1578409.DC1 \\ Material}

References This article cites 73 articles, 43 of which can be accessed free at: http://rnajournal.cshlp.org/content/15/8/1528.full.html\#ref-list-1

\section{License}

Email Alerting Receive free email alerts when new articles cite this article - sign up in the box at the Service top right corner of the article or click here.

To subscribe to RNA go to:

http://rnajournal.cshlp.org/subscriptions 